\title{
Türk Romanında Sembolik Değerleri Bağlamında Fes-Şapka Mücadelesi
}

\section{The Fez-Hat Struggle in the Context of Symbolic Values in the Turkish Novel}

\author{
Mehmet Doğan ${ }^{1}$
}

${ }^{1}$ Doktora öğrencisi, Yüzüncü Yıl Üniversitesi, Sosyal Bilimler Fakültesi, Türk Dili ve Edebiyatı Bölümü, Van, Türkiye

ORCID: M.D. 0000-0002-6336-2389

\author{
Sorumlu yazar/Corresponding author: \\ Mehmet Doğan, \\ Doktora öğrencisi, Yüzüncü Y1l Üniversitesi, \\ Sosyal Bilimler Fakültesi, Türk Dili ve Edebiyatı \\ Bölümü, Van, Türkiye \\ E-mail: me.dogan02@gmail.com
}

Başvuru/Submitted: 21.10.2020

Revizyon Talebi/Revision Requested: 28.10.2020 Son Revizyon/Last Revision Received: 06.11.2020 Kabul/Accepted: 06.11.2020

\section{Atıf/Citation:}

Dogan, M. (2021). Türk romanında sembolik değerleri bağlamında fes-şapka mücadelesi. TUDED, 61(1), 123-149.

https://doi.org/10.26650/TUDED2020-813828

\section{ÖZET}

Kılık-kıyafet kişinin mensup olduğu medeniyetin, kimliğinin, siyasi tercihlerinin, mevkiinin veya ekonomik durumunun göstergesi de olabilecek sembolik bir değere ve anlama sahiptir. Küreselleşmeyle birlikte kılık-kıyafette nispi bir tek tipleşmeye doğru gidildiğinden bu belirleyicilik kimi zaman yanıltıcı olsa da, medeniyetlerin keskin çizgilerle birbirlerinden ayrıldıkları dönemlerde ve ülkelerde, denilebilir ki, en keskin ayrım kılık-kıyafet üzerinden görülür. Özellikle gelenekçi, değişime direnen toplumlarda giyim, tabu olarak sembolik değer ve anlamını korur. Sembolik bir anlam ve değer taşıyan, en azından bu makalenin konu edindiği 19. yüzyıl sonu ile 20. yüzyılın başlarında, en önemli giysi ise şüphesiz ki başlıklardır. Başlıkların değiştirilme girişimleri aslında radikal değişimlerin birer sembolü ve iktidara itaatin göstergesi olarak görülmüştür. Kimliğin, zihniyetin, statünün ve dinin sembolü olarak görülen başlıklar zihniyet değişiminin hem en sancilı süreci olmuş; hem de en belirgin göstergesi olarak toplumsal yaşama ve edebi eserlere yansımıştır.

$\mathrm{Bu}$ makalede, edebi yapıtlardan hareketle medreselilerin ve mutasavvıfların sardığ sarık, Müslüman Osmanlı halk topluluğunun başlığı olan fes, Kuvâ-yı Milliye taraftarlarının kullandığı kalpak ve Batı'dan alınan şapkanın Türk toplumundaki algısı, anlam ve değerleri belirlenmeye çalışılacaktır. Makale, festen şapkaya geçişi yaşayan edebiyatçıların eserleriyle sınırlandırılmış, ele alınan yazarların bu değişimin izlerini taşıyan değerlendirmeleri ortaya konulmaya çalışılmıştır. Makalenin amacı edebiyat sosyolojisi yönteminden hareketle toplumun şapka karşısındaki reaksiyonlarının nedenlerini belirleyebilmektir.

Anahtar Kelimeler: Fes, Şapka Kanunu, sarık, sembolik değer, kılık-kıyafet

\section{ABSTRACT}

Dress has a symbolic value and meaning that can be an indicator of the civilization, identity, political preferences, position or economic status of the person. Although this decisiveness is sometimes misleading as there is a relative uniformization of dressclothing with globalization, it can be said that the sharpest distinction is seen through dress-clothing in periods and countries where civilizations are separated from each other by sharp lines. Especially in traditionalist societies that resist change, clothing preserves its symbolic value and meaning as a taboo. The most important garments that carry a symbolic meaning and value, at least in the late $19^{\text {th }}$ and early $20^{\text {th }}$ centuries that this article is about, are undoubtedly the headdresses. Attempts to change the headlines were actually seen as symbols of radical changes and a sign of obedience to power. In this article, we will try to determine the perception, meaning and values of the turban worn by the madrasians and Sufists, the fez, the headdress of the Muslim Ottoman community, the kalpak used by the supporters of the Kuvveyi Milliye, and the hat taken from the West in the Turkish society based on literary works.

Keywords: Fez, Hat Law, Turban, symbolic value, costume-dress 


\section{EXTENDED ABSTRACT}

The greatest factor in Fez reaching large masses in the Muslim Ottoman society was II. It is the decree issued by Mahmud (1826). It is stated that the main reason for the popularization of the fez, which is accepted as the official "clothes" after the abolition of the Janissary House, is "Sultan Mahmut Han's determination to leave no memories and works resembling the old age in order to eradicate the janissary" (Pakalın, 1993: 611). Since there is no unity of dress in the Ottoman society, fez is assigned as a common heading for "members of every religion and community in order to eliminate the dressing difference between Muslims and non-Muslims" (Pakalın, 2013: 614). Fes was first imported from Tunisia and France (1826), and later from Austria (1832). Austrian goods are boycotted because Austria, from which the fezes were imported, attacked Bosnia-Herzegovina. Due to this boycott, fezes were removed and thrown on the ground.

When we look at the fez-hat debates in the Republican era, we encounter interesting scenes. First of all, there is an expectation and a desire, at least in a certain intellectual environment, to wear hats. Considering the information given in various memoirs, it is understood that Mustafa Kemal had the disguise and dress reform long before he was going to do it, and he was waiting for a suitable time to realize it. With a Council of Ministers Decree published on September 2, 1925, it is made obligatory for civil servants to "wear the hat that the people spontaneously wear". On October 16, a law proposal on "Hat Economy" is made; The law comes into force on 28 November 1925. The hat revolution should be viewed as an attempt to eliminate everything that reminds the old, thus delaying or preventing the setting of the new, rather than becoming westernized.

The socio-cultural clues behind the biggest reaction of the reforms against the Hat Revolution can be captured from these narratives. Historical texts are insufficient to explain the dimensions and reasons of this social reaction. On the other hand, the presence of some details in the relevant literary texts that provide material for sociological readings partially gives clues to the mysteries of this social reaction. Looking at today's value judgments, it is not possible to understand neither the hat revolution nor the reaction against this revolution. Historical texts are far from giving this to us. Although it is not reflected in literary texts in a neat way, it is possible to trace the symbolic value that the people of the period attributed to the hat and fez from some scraps scattered among them.

The novel is open to sociological readings; Therefore, they are the reference sources for the enlightenment of the periods, mentalities and events. Of course, this determination should be made, considering that fiction-based genres are not exactly history or sociology. So what; Sometimes and events based on fiction gain more importance than historical documents, sometimes they can be a source almost alone for sociological determinations. In this context, the novels of the period are important sources for understanding the reforms of the Atatürk period and evaluating them with a more accurate expression. Although it caused mass reactions, 
as far as we can see, we have not encountered any novel that tells about the effects of the Hat Law, or at least partially that deals with these reactions. However, we tried to reach a whole based on the information given in one or a few sentences in some novels.

Halide Edip, one of the authors discussed in the article, had negative feelings towards the hat. Halide Edip's “assimilation of the Eastern-Islamic culture with his heart, though he is Western with his mind" is effective in this. However; he seems to have adopted the hat in his later novels. Yakup Kadri drew attention to the hat with a story in a very early period among the writers discussed, and stated indirectly, even if not directly, that the society found the hatred of the hat as exaggerated and unnecessary. However, the fact that the fez, whose symbolic value came to the fore during the years of the War of Independence, was not digested by the occupying officers, also reflected in his novel. On the other hand, Peyami Safa; He mentions in his novels that being headless was not accepted for a man during the Ottoman period. From his narrative there is the impression that he finds this imposition of tradition unnecessary. Hat or fese, on the other hand, does not impose symbolic meanings and values that go beyond their own. Although Refik Halit Karay reflects the symbolic meaning attributed to the fez and hat by the society, it does not express a value judgment in his expression. Kemal Tahir sees the hat as an indicator of a mentality change. 


\section{GíRIŞ}

"Dervişlik olsaydı taç ile hırka ile

Biz de alır idik, otuza kırka"

Yunus Emre

Osmanlı toplumunda dinî aidiyetleri ve statüleri belirleyen başlıklar sıkı bir düzene tabidir. ${ }^{1}$ Bu başlıklara bakarak kişinin statüsünü, fikriyatını, mesleğini, dinini, mezhebini, tarikatını hatta tarikattaki mevkiini bile belirlemek mümkündür. "Bir toplumun kullandığg başlıkları (şapkaları) inceleyerek, toplumun kültürüyle veya yaşam biçimlerinden, manevi değerlerine kadar çıkarımda bulunmak mümkündür.” (Erkuş, 2013: 3) Osmanlı toplumunda esnaf da yaptığı iş koluna uygun bir kavuk giymek zorundadır. "Başlık kişiyi temsil etmede o kadar önemli bir özelliğe sahipti ki, öldükten sonra da mezar taşına kazınmaktadır” (Abalı, 2009: 188). Ne var ki değişen iktidarlar ve gelişen olaylar, zihniyetin de değişimini imleyen başlik değişimlerine neden olmuştur. Bu bağlamda özellikle sarıktan fese, festen şapkaya geçiş süreci sancılı olmuştur. Sancılı toplumsal süreçler yaşanmasına neden olan başlık değişimleri, topluma ayna tutma iddiasındaki romana da yansımıştır. II. Mahmut döneminde fes takılmasını zorunlu tutan bir fermanın yayımlanması, Cumhuriyet' in ilk yıllarında şapka takılmasını zorunlu hale getiren bir kanunun çıkarılması ve halkın, en azından belli bir kesiminin, fes-şapka giymemek için ciddi direnç göstermesi başlıkların sadece takı olarak algılanmadığının bariz göstergesidir.

Bir giysi olarak başlığın değiştirilmesiyle bir zihniyetin de dönüştürüleceğine, en azından otoritenin tanınmasını/itaati imlediğine olan inanç, iktidar sahiplerinin otoritelerini sağlamlaştırmak ve muhalif hareketler üzerindeki baskılarını pekiştirmek için de firsat sunmuştur. Bu nedenledir ki iktidara gelenler kendi adlarıyla anılan başlıkları kimi zaman mecbur tutarak kimi zaman da moda haline getirerek yaygınlaştırmışlardır. "Gözlemler göstermektedir ki, ister dini olsun, ister felsefi olsun, başarılı olmak isteyen her 'ideoloji', toplumsal hayatta kendine has 'modalar' meydana getirmek istemektedir. Yani, milletlerarası 'moda etkileşimi' olduğu kadar, ideolojiler arası 'modalar' da vardır.” (Abalı, 2009:126) II. Mahmut'un taktığı fes türüne "mahmudiye”, II. Abdülhamit’ in taktığı fes türüne "hamidiye”, Enver Paşa'nın I. Dünya Savaşı'nda özellikle Güney cephelerine sevk edilen askerlere zorunlu tuttuğu başlık türüne "Enverî" denilmesi de muktedirlerin kendilerine ait bir moda oluşturma arzusunun olduğunu gösterir. Mustafa Kemal'in taktığı başlık, kendi adını taşımasa da, benzer bir işlev amacı taşır.

İktidarlar benimsediği kimliğin sembolünü tebaasının üstünde görmek istemiştir. Bu; ideolojik, düşünsel bir dönüşümü göstermek arzusu olduğu kadar iktidarına biat edilmesinin

1 "Halktan olan erkekler... başlarına yumuşak bir takke veya yumuşak bezden bir sarık sararlar. Diğger Şeyhülislam, kadı, asker, yüksek rütbeli ulema örfi kavuk giymektedirler. 1828'den önce 'kâtip sınıfi' denilen devlet memurları devlet dairelerinde 'kâtibi kavuk' giyerler. İlmiyeliler denilen din adamları grubu ise 'Molla kavuğu' denilen bir kavuk türü kullanmışlar. Dervişler, kahverengi keçe külah, hocalar ise yeşil sarık sarmışlar... Bir kişinin dini, giymiş olduğu başlıktan rahatça anlaşılabilir. Bu da, giyim kuşam alanındaki farklılığın, bilhassa başlık konusunda çok hassas bir biçimde dikkat edildiği görülür. Müslümanlarca kullanılması adet olmayan bir elbise, hele bir başlık irtidat sayılır." (Abalı, 2009: 189-193) 
sembolü olarak da görülmüştür. Bu dönemlerde takılan başlık; iktidara, otoritenin benimsediği politikalara boyun eğmenin alameti kabul edilmiştir. Aksi durum ise muhalifliğin sembolü olarak algılanmıştır. Otoritelerin başlık dayatması, simgesel anlamda toplumdaki muhalefeti bertaraf etmek, rejimi kuvvetlendirmek ve nafile bir çaba olarak herkesin aynı zihniyete dönüştürülmesini sağlamaya yönelik bir çabadır.

\section{SARIKTAN FESE, FESTEN ŞAPKAYA: ZIHNIYET VE OTORITTENIN SEMBOLÜ}

Romanlara yansıyan fes-şapka mücadelesine başlamadan önce fesin ortaya çıkması, yaygınlaşması ve sembole dönüşmesiyle Şapka Kanunu'nun çıkarılmasına giden sürece kısaca değinmekte fayda var. Bir başlık türü olan fesin kökeniyle ilgili birbirinden farklı görüşler vardır. ${ }^{2}$ Konumuzla ilgili olarak biz sadece yaygınlaşıp bir sembole dönüşmesini ele alacağız. Fesin Müslüman Osmanlı toplumunda geniş kitlelere ulaşmasında en büyük amil II. Mahmud'un çıkardığı fermandır. Yeniçeri Ocağı'nın ortadan kaldırılmasından sonra resmi "serpuş" olarak kabul edilen fesin yaygınlaştırılmasındaki asıl sebebin de "Sultan Mahmut Hanın, yeniçeriliğin kökünü kazımak için eski devri andırır hiçbir hatıra ve eser bırakmamak azmi” olduğu ifade edilir (Pakalın, 1993: 611). Köklü yeniliklerin yapıldığı II. Mahmut döneminde çıkarılan bir nizamname ile fesin önce askerler sonra diğer memurlar için zorunlu hale getirilmesi ${ }^{3}$ muhafazakâr kitle tarafindan tepkiyle karşılanmış, "Padişah II. Mahmut vermiş olduğu kararı uygulatmak için Şeyhülislam Mehmet Tahir Efendi'yi azletmekten bile çekinmemiş ve ilk aşamada kullanılmak üzere Tunus’tan 50.000 fes getirtmiştir.” (Aysal, 2011: 7) Osmanlı toplumunda bir kıyafet birliği olmaması nedeniyle "Müslümanlarla gayri Müslimler arasındaki giyim farkını kaldırmak üzere, her din ve cemaat mensubu için" fes müşterek bir başlık olarak tayin edilir (Pakalın, 2013: 614). Fes, ilk zamanlar Tunus ve Fransa'dan, sonraları ise daha çok Avusturya'dan ithal edilir. Memleketten büyük bir paranın çıkmasına sebep olduğu için 1833 'te İzmit'te bir “dinkhane", 1835'te İstanbul'da "Feshane" adı verilen fabrika kurulur (Pakalın, 1993: 614). Feslerin ithal edildiği Avusturya’nın, BosnaHersek'e saldırması nedeniyle Avusturya malları boykot edilir. Bu boykot nedeniyle de fesler çıkarılarak yerlere atılır. Öyle ki mitinglerde feslerini çıkarıp yırtmayanların fesleri başlarından alınarak yırtılır, “İzmir'deki bir protesto gösterisi, bazı çocukların feslilere saldırıp feslerini

2 Ayrıntılı bilgi için, Mehmet Zeki Pakalın’ın Osmanlı Tarih Deyimleri ve Terimleri Sözlüğü’nün birinci cildinde bulunan "Fes" maddesine bakılabilir. Ayrıca Mehmet Emin Elmacı'nın "Fes-Kalpak Mücadelesi” adlı makalesinde de konuyla ilgili detaylı bilgi verilmektedir.

3 Mehmet Zeki Pakalın, II. Mahmud'un Avrupa'dan da birkaç “serpuş” örneği de getirttiği ama bunların namaza mani olduğu için fesi “münasip” gördüğünü belirtirken (Pakalın, 1993: 611), Nurullah Abalı ise, "II. Mahmut şapkaya geçebilmek için fesi bir ara unsur olarak görmüştür." (Abalı, 2009: 196) demektedir. Konuyla ilgili Mehmet Emin Elmacı'nın ifade ettikleri de dikkat çekicidir: “II. Mahmud festen önce Avrupa'dan getirttiği şapkaları denemiş ve sonunda yeni üniformasıyla ilk cuma selamlığına çıkmak için başında şapkasıyla ayna karşısında kıyafetini incelerken, Valide Sultan'ın ağlamasıyla bundan vazgeçmiş ve fesi tercih etmişti.” (Elmacı, 1997: 28)

4 Osmanlı Devleti'nde Hıristiyanların yaşayış biçimleri Müslümanlardan ayrılmış ve bunların kendilerine benzememeleri konusunda dinî bir titizlik gösterilmiştir. Gayrimüslimler yaşayışlarında ve giyimlerinde birçok kayıtlara tabi tutulmuşlardır. Giyebilecekleri kıyafetler divandan çıkan hükümlerle belirlenir, onlar bu hükümlerin belirlediği kıyafet dışında elbise giyemezler, aksi halde cezalandırılırlardı. 
yırtmaya başlamaları üzerine, bir fes yırtma bayramına dönüşmüş[ür]." (Elmacı, 1997: 30) Kalpak ve keçe külahın tercih edilmeye başlamasıyla birlikte fes satıcıları ile kalpak ve keçe külah satıcıları arasında da gerilim baş gösterir. İlginçtir ki fes nedeniyle II. Mahmud'a "gâvur padişah" diyen muhafazakâr camia yaklaşık bir yüz yıl sonra, 1908'de, fesleri yerlere atarak yırtmış, hatta dinen fes giyilmesinin uygun olmadığını dillendirmişlerdir. 1925 yılında ise, aynı fes için bu kez "dini başlığımızdır” diyerek canla başla sahip çıkmışlardır. (Elmacı, 1997: 28)

20. yüzyıla gelindiğinde de Osmanlı ordusu içinde askeri kıyafetler konusunda yine önemli değişiklikler yapılır. 1903’te II. Abdülhamid, “topçu ve süvari askerlerine fes yerine kalpak giydirmek istediğinde, daha önce fesi dine aykırı bulup, karşı çıkanlar, bu kez de fesi savunup, kalpağa karşı çıkmışlardır. XIX. yüzyılın sonlarında devlet gücüyle giydirilen fesin köylere kadar yayıldığı ve artık dinin bir simgesi haline geldiği görülecektir.” (Aysal, 2011: 7) 1909' da da “Elbise-i Askeriye Nizamnamesi” çıkartılarak askerlerin kıyafetlerinde değişikliğe gidilir. Osmanlı' da Müslüman halkın şapka giymesine kesinlikle müsaade edilmez; bununla birlikte 20. yüzyılın başlarından itibaren Osmanlı aydınlarının yurt dışına çıktıklarında şapka giydikleri çeşitli hatıratlarda aktarılır. ${ }^{5}$

Başlığın mücadelede simge haline gelişinin bir başka örneği Milli Mücadelede kalpağın kullanılmasıdır. Kuvayı Milliyeciler, fesli İstanbul'a, şapkalı Hristiyan işgalcilere karşı sembol olarak kalpağı seçmişlerdir. Kalpak, kısa zamanda direnişin simgesi haline gelmiştir. (Abalı, 2009: 204)

Başlıkların değiştirilme girişimlerinin aslında radikal değişimlerin birer sembolü olduğunu İsmail Habip Sevük'ün şu ifadeleri net olarak ortaya koymaktadır: "Kavuk ümmetimiz, fes Osmanlılığımız, kalpak ihtilalimiz, şapka inkılâbımızdır.” (Özdemir, 2017: 42)

Cumhuriyet döneminde fes-şapka tartışmalarına baktığımızda ilginç sahnelerle karşılaşırız. Öncelikle şapka giyilmesine yönelik, en azından belli bir aydın çevresinde, adeta bir beklenti ve istek vardır. Peyami Safa'nın aktardığına göre İçtihâd mecmuasında “Pek Uyanık Bir Uyku” başlıklı iki yazı yayımlanır, bu iki yazıda garpçıların bütün istekleri numara sırasıyla hulâsa edilir. Safa, bu isteklerden birinin de "Fes kâmilen defedilip yerine yeni bir serpuş kabul olunacaktır" maddesinin olduğunu belirtir. (Safa, 2010: 34) Abdullah Cevdet de Şapka Kanunu'nun çıkmasından bir y1l önce, “1 Eylül 1924’te İçtihâd' da yayımlanan 'Şapka ve Fes' isimli makalesinde, Hayrettin Bey isimli bir Müslüman'ın başındaki şapkası ile İstanbul' da gezerken zabıta tarafından tutuklandığını belirterek bu durumun Cumhuriyet'e yakışmadığını” ifade eder (Aysal, 2011: 15).

Çeşitli hatıratlarda verilen bilgiler göz önüne alındığında aslında Mustafa Kemal'in kafasında, yapacağı kılık ve kıyafet inkılâbının çok önceden var olduğu, bunu gerçekleştirmek için uygun bir zaman kolladığı anlaşılır.

Erzurum Kongresi'nin açılış hazırlıklarının devam ettiği günlerde, 7-8 Temmuz 1919 tarihinde, Mustafa Kemal zafere ulaştıktan sonra yapacağı inkılâpları Mazhar Müfit Bey’e not

5 Örnek olarak; Falih Rıfkı Atay’ın Çankaya, Yahya Kemal'in Çocukluğum, Gençliğim, Siyasi ve Edebi Hatıralarım ile Necip Fazıl'ın Kafakağıd $ı$ adlı eserlerine bakılabilir. 
ettirir: "Bir: Zaferden sonra hükümet biçimi Cumhuriyet olacaktır. İki: Padişah ve hanedan hakkında zamanı gelince gereken muamele yapılacaktır. Üç: Tesettür (örtünme) kalkacaktır. Dört: Fes kalkacak, uygar milletler gibi şapka giyilecektir...” (Hür, 2013: 296) Mustafa Kemal'in fesle ilgili erken dönemlerde yaşadığı iki kötü hatıra da bu inkılâbın psikolojik zeminini hazırlamıştır. ${ }^{6}$

İlk olarak 24 Ağustos 1925 'te Kastamonu ve İnebolu'ya yaptığı gezilerde şapka giyerek halkı yapılacak bu inkılâba hazırlayan Mustafa Kemal, kendisini karşılamaya gelen halka karşı yaptığı konuşmada giyim kuşamdaki karmaşaya dikkat çeker. 2 Eylül 1925 'te yayımlanan bir Bakanlar Kurulu Kararnamesi ile devlet memurlarına "halkın kendiliğinden giymeye başladığ şapkayı giymeleri zorunlu” hale getirilir. 16 Ekim'de de "Şapka İktisası" hakkında kanun teklifi verilir. 25 Kasım'da görüşülmeye başlanan teklif Bursa milletvekili Nurettin Paşa ile Siverek milletvekili İhsan Ergani Bey’in dışındaki milletvekillerince kabul edilerek 28 Kasım 1925 'te yürürlüğe girer.

Türkiye Büyük Millet Meclisi azaları ile idare-i umumiye ve mahalliyeye (genel ve yerel idare) ve bilumum müessesata (kurumlara) mensup memurin ve müstahdemin Türk milletinin iktisa etmiş olduğu şapkayı giymek mecburiyetindedir. Türkiye halkının da umumi serpuşu şapka olup buna münafi bir itiyadın devamını (buna aykırı bir alışkanlığın devamını) Hükümet men eder. (Aysal, 2011: 18)

Mustafa Kemal'in, fesi “cehil, gaflet ve taassubun ve terakki ve temeddün düşmanlığının alâmeti fârikası" olarak, şapkayı ise "Türk milletinin medeni hayat-1 içtimaîyeden, zihniyet itibariyle de hiçbir farkı olmadığını[n]" göstergesi olarak gördüğü ifadelerinden anlaşılmaktadır. Yani "başlığa" kendisini aşan bir anlam yüklenmiştir. Eskiye ait olan, eskiyi hatırlatan her şeyin bertaraf edilmesi, yeni rejimin yönelimlerini de göstermesi açısından önemlidir. Şapka inkılabını Batılılaşmaktan ziyade, eskiyi hatırlatan, dolayısıyla yeninin yerleşmesini geciktiren, engelleyen her şeyin bertaraf edilmesine yönelik bir girişim olarak görmek gerekir. "Cumhuriyet seçkinleri gerçekleştirmek istedikleri inkılâp çalışmalarında o kadar titizlerdi ki, görünüm olarak geleneksel kimliği yansıtacak en küçük simgeye müsamaha göstermemiştir.” (Erduğan, 2019: 60) Ayrıca toplumda kıyafet birliğinin olmaması, bu anlamda tam bir kaosun yaşanması da yapılan bu inkılâpta bir etken olarak gösterilmiştir. ${ }^{7}$

6 'Fesi Türkiye sınırları içinde kaldıracak olan Atatürk'ün fese karsı tepki geliştirmesine sebep olan olaylar 1908 ile 1913 arasında meydana geldi. Bu olayların ilki Mustafa Kemal'i, Trablus'a götüren vapurun Sicilya'ya uğramasıyla yasandı. Mola sırasında açık fayton kiralayıp şehri dolaşmaya çıkan Mustafa Kemal, mahalle çocuklarının 'fesli yabancı'yı limon kabuğuna tutmasıyla karşılaştı. Bu olaya tepkisini söyle dile getirmişti: 'Sicilyalı çocukların terbiyesizliğine değil, neden böyle yabani bir baslığa esir olduğuma kızmıştım.' İkinci olay ise Fransa'da Pikardi askeri manevraları sırasında yaşandı. Her ülkeden gelen subayların tartışmaları sırasında Mustafa Kemal genellikle Avrupalı uzmanların savunduğunun aksi bir tezi savundu. Dinleyiciler bu sözlere dudak büktüler. Oysa iddianın doğruluğu ertesi gün manevraların gelişmesiyle ortaya çıktı. O zaman bir yabancı albay bu dudak bükmenin nedenini şöyle açıkladı: 'Sizin görüşünüzün doğru olduğu dün aksamdan belliydi. Fakat... ne diye bu tuhaf başlığı giyersiniz? Başınızda bu oldukça kafanıza kimse itibar etmez.” (Özdemir, 2007: 20)

7 Mustafa Kemal'in şapkayı ilk olarak tanıttığı İnebolu ve Kastamonu gezilerinde yaptığı konuşmaların merkezinde giyim kuşamdaki bu kaos vardır. 
Türkiye'de festen şapkaya geçişte toplumsal bir sarsıntı meydana gelir. Bu sarsıntılardan en büyüğü, gazete ve dergilerde konuyla alakalı olarak yayımladıkları yazılar ve kitaplarla dönemin hafızasına kazınan İskilipli Atıf-Süleyman Nazif polemiği olur. İskilipli Atıf Hoca’nın Şapka Kanunu çıkmasından bir yıl önce yazdığg Frenk Mukallitliği ve Şapka adındaki eserinde ileri sürdüğü düşüncelere karşı Süleyman Nazif onun düşüncelerini çürütmeye yönelik fikirler öne sürer. Bu tartışmalar hararetli bir şekilde sürerken Şapka Kanunu çıkar ve İskilipli Atıf bu kitabı da bahane gösterilerek hapse atılır ve ardından da idam edilir.8 "Şapka inkılâbı aleyhine ülkenin çeşitli yerlerinde pek çok olay çıkar, 808 kişi sanık olarak yargılanır ve 57 kişi idama mahkum edilir." (Aysal, 2011: 20) Pek çok hatıratta aktarılanlar da göz önünde bulundurulduğunda, ele aldığımız romanlarda görülen sahnelerin gerçek yaşamın izdüşümü olduğu anlaşılır. Yapılan inkılâplar arasında en büyük reaksiyonun Şapka İnkılâbı'na karşı olmasının arkasındaki sosyo-kültürel ipuçları bu anlatılardan hareketle yakalanabilir. Başa geçirilen şapkanın neden olduğu polemikler kadar ilgili kanunun diğer inkılapların hepsinden daha fazla toplumsal bir reaksiyona maruz kalması da dikkat çekicidir. Konuyla ilgili edebi metinlerde, sosyolojik okumalara malzeme sunan bazı ayrıntıların bulunması, bu toplumsal reaksiyonun gizemlerinin ipuçlarını kısmen vermektedir. Günümüz değer yargılarıyla bakıldığında ne şapka inkılabını ne de bu inkılaba karşı gösterilen reaksiyonu anlayabilmek pek mümkün değildir. Bununla birlikte edebi metinlere derli toplu bir şekilde yansımadığ 1 halde araya serpiştirilen bazı kırıntılardan dönem insanlarının şapkaya ve fese yükledikleri sembolik değerin izlerini sürmek mümkündür. Bununla birlikte dikkat edilmesi gereken bir nokta da, "Halkın direnç gösterdiği ve karşı olduğu devrimlerin teknolojik kısmından ziyade kültürel değerlerdir. Bu kültürel değerlerin değişimi, toplumun tabanından gelen isteklerle değil; tepeden inmeci bir azınlığın zora dayanarak yaptığı çalışmalardan kaynaklanmaktadır." (Erduğan, 2019: 86)

Şapka, en azından dış görüntü itibariyle, İslam medeniyeti ile Batı medeniyetinin sınır çizgisi olan bir sembol kabul edilmiş, bu nedenle halk arasında haç-hilal kadar bir temsiliyet kazanmıştır. Şapkanın/şapka giyenlerin Osmanlı toplumunda “öteki” olarak algılanmasının köklerinin eskiye dayandığını, 17. yüzyılda yaşayan ünlü halk şairlerinden Karacaoğlan'ın “Frengistan’ı Seyran” şiirindeki şu dizelerden çıkarmak mümkündür:

Akılları yoktur küfre uyarlar,

İmanları yoktur cana kıyarlar,

Başlarına siyah şapka giyerler,

Beğleri var bizim beğe benzemez (Sar1, 2016: 344)

8 İskilipli Atıf'ın idamına giden yolda adı geçen kitabının rolü üzerine tartışmalar günümüzde hala canlılığını korumaktadır. Üstelik taraflar kendilerini haklı çıkaran dokümanlar da bulabilmektedir. Bu makalenin çerçevesinin dışında olduğundan bu tür tartışmalara yer verilmemiştir. 


\section{SIMGESEL DEĞERLER BAĞLAMINDA ROMANA YANSIYAN FES-ŞAPKA MÜCADELESİ}

Kurguya dayalı bir tür olan romana yansıyan fes-şapka motifi de anılara yansıyan simgesel değere paralellik gösterir. Bu makale, hem fesin takıldığı hem de Şapka Kanunu'nun çıktığ 1 döneme şahit olan yazarların eserleriyle sınırlandırıldı. Bu değişime şahit olan yazarların romanlarına yansıyan tasvirlerin daha gerçekçi olabileceği göz önünde bulundurulması bunda etkili oldu.

Roman sosyolojik okumalara açıktır. Dolayısıyla dönemlerin, zihniyetlerin ve olayların aydınlatılmasında veriler sunabilmektedir. Elbette kurguya dayalı türlerin birebir tarih veya sosyoloji olmadıkları göz önünde bulundurularak bu tespit yapılmalıdır. Ne var ki; kimi zaman ve olaylarda kurguya dayalı türler tarihi belgelerden daha fazla önem kazanmakta, sosyolojik tespitler için de kimi zaman neredeyse tek başlarına birer kaynak olabilmektedir. Atatürk dönemi inkılaplarının anlaşılması, daha doğru bir ifadeyle değerlendirilmesi için dönemin romanları bu bağlamda önemli kaynaklardır. Kitlesel tepkilere sebep olmasına rağmen görebildiğimiz kadarıyla Şapka Kanunu'nun etkilerini anlatan, en azından bir bölümüyle de olsa bu reaksiyonları konu edinen herhangi bir romanla karşılaşmadık. Bununla birlikte bazı romanlarda bir veya birkaç cümleyle verilen bilgilerden hareketle bir bütüne ulaşmaya çalıştık.

Ahmet Mithat'tan Ömer Seyfettin'e pek çok edebiyatçının eserlerinde fes-şapka motifinin simgesel değer göstergesi olarak kullanıldığını görmek mümkündür. Biz bu çalışmayı; fesin toplumsal bir değer olarak kabul edildiği günlere de, şapka giymenin yeni kurulan cumhuriyete bağlılık olarak algılandığı zamana da şahit olan edebiyatçıların kurgusal nitelikteki eserleriyle sinırladik.

\section{ŞAPKAYA AÇIKTAN DUYULAN BÜYÜK HAYRANLIK: YAKUP KADRI'NIN ESERLERINDE ERKEN DÖNEM ŞAPKA MOTIFİ}

Eserlerinde k1lık-kıyafeti bir zihniyetin en keskin göstergesi olarak ele alan Yakup Kadri, eserlerini kaleme aldığ dönemin zihniyet değişimlerini de elbiseler üzerinden verir. Yakup Kadri’nin yaşadığı yılların Türk toplumunda en çalkantılı ve hızlı değişsim dönüşümlerin yaşandığı dönem olduğu göz önüne alındığında ise doğal olarak birbirinden farklı bir Yakup Kadri ile karşılaşırız. Çünkü, "Karaosmanoğlu ise Türk toplumunun sorunlarına tarihsel açıdan bakmaya çalışır. Bundan ötürü de romanlarının bir ikisi dışında ötekiler, belli tarihsel dönemlerin romanıdır.” (Moran, 2001: 179) Romanlarında çeşitli imgelerle anlattı̆̆ tarihsel kırılmalar, sosyal değişimler, siyasal dönüşümler kendi yaşantı ve gözlemlerinin aktarımıdır. Dolayısıyla romanlarındaki kılık-kıyafet üzerinden yaptığı tespitler bir yandan bize Yakup Kadri'nin düşünsel serüvenini izlememize olanak sunarken diğer yandan da bu değişimlerin toplum yaşantısına akseden izdüşümlerini görmemizi sağlar. Romanlarındaki fes-şapka izleğine geçmeden önce yazarın kıyafet ile zihniyeti, kıyafet ile şahsiyeti ilk eserlerinden itibaren birlikte değerlendirdiğini aşağıdaki alıntıdan belirleyebiliriz. 
İstanbul'da iki devir oldu: Biri İstanbulin; diğeri redingot devri... Osmanlılar hiçbir zaman bu İstanbulin devrindeki kadar zarif, temiz ve kibar olmadılar. Tanzimatı Hayriye'nin en büyük eseri, İstanbulinli İstanbul Efendisidir. Bu kıyafet dünyaya yeni bir insan tipi çıkardı ve Türkler bu kıyafet içinde ilk defa olarak vahşi Asya ile haşin Avrupa'nın arasında gayet hususi yeni bir millet gibi göründü... Zira, bu beyaz pantolonlu, beyaz yelekli ve lüstrin kaloşlu Türkler, ince bir halattan ibaret endamlariyle biraz evvelki boğum boğum adamlara hiç benzemiyorlardı... Yüksek rütbeli devlet adamlarının tesis ettikleri Osmanlı kibarlığının kundağ ve serapa (Baştanbaşa) ilikli İstanbulin idi.

Sonra redingot devri geldi ve redingotun içinden yarı uşak, yarı kapıkulu, riyakâr, adi bir nesil türedi. Bu neslin en yüksek, en kibar simalarında bile bir saray hademesi hali vardı. Çoğu, ikinci Abdülhamit Han devri ricalinden olan bu adamların her biri bir hile ile efendilerinin arabasına binmiş seyisleri andırıyorlardı. (Karaosmanoğlu, 1996: 6-7)

Yakup Kadri’nin konuya bakışındaki değişimi görebilmek açısından romanlarını sıradizimsel olarak ele alacağız.

Ele alınan yazarlar içinde, Osmanlı Devleti'nde Müslüman unsurların şapkaya bakışını ilk ele alan Yakup Kadri'dir. 1914 yılında, yani Cumhuriyet'in ilanından bile çok önce, yayımlanan Bir Serencam adlı öykü kitabında "Şapka" adında bir öyküsü vardır. Bu öyküde anlatılanlardan hareketle o dönemde şapkaya yüklenen anlamı ve toplumun buna karşı gösterdiği reaksiyonu, öykünün geneline yayılan korku atmosferinin de etkisiyle, anlamak mümkündür. Öyküde anlatılan olaylar İzmir'de geçer. İtalyan Madmazel Claire Cortiso, kardeşinin "fötr şapkasını" Fazıl ismindeki Müslüman nişanlısının başına takar. Şapkanın kendisine çok yakıştığını belirterek başında şapkayla gezmeye çıkmak ister. Bu öneri karşısında kızın babası Mösyö Cortiso’nun verdiği tepki, o dönem Müslüman toplumun şapkaya bakışını da ele verir:

...bu memleketin her sınıf halkı senin kim olduğunu bilir. Senin şapka giymen, eminim ki İzmir'de bir ihtilale sebep olur... Türkleri İtalyanlardan daha iyi tanırım: Eski adetlerine, an'anelerine bu kadar şiddetle merbut bir kavim daha tasavvur edemiyorum. (Karaosmanoğlu, 1990: 74)

Ne var ki bu sözleri kızı tarafından hayretle karşılanır. "Bir başın serpuş değiştirmesiyle bir ihtilal arasında" bir münasebet olduğuna inanmaz. Fazıl da müstakbel kayınbabasına Türklerin onun zannettiği gibi "körcesine mutaassıp" olmadıklarını göstermek için başına fötr şapka takarak nişanlısıyla dışarı çıkmayı kabul eder. Ne var ki dışarı çıktığı andan itibaren kendisini tanıyan kişilerin bakışından ürkmeye başlayan Fazıl, daha fazla kimseye görünmeden nişanlısının teyzesinin evine ulaşmaya çalışır. Tramvayda karşılaştığı, kendisini tanıyan birinin bakışlarından ve yanındakilerle "mahfi ve esrarlı" konuşmasından daha da ürker. Fazıl'ı takip eden kişiler şapka takması nedeniyle Fazıl'a sataşırlar. "Görüyor musun rezil!... her yaptığı yetmemiş gibi şimdi de şapka giyiyor.” (Karaosmanoğlu, 1990: 86) Öykünün sonunda Fazıl nişanlısının gözleri önünde kendisini takip eden bu iki kişi tarafından şapka taktığı için dövülerek 
öldürülür. Yakup Kadri’nin bu öyküsünün satır aralarında gördüğümüz tavrı, ele alacağımız diğer yazarların aksine, Şapka Kanunu'yla takındığı tavırla uyumludur. Karaosmanoğlu, bir başlığa mutaassıp derecesinde bağlanmayı eleştirdiği gibi, anlatımından anladığımız kadarıyla, şapka giymeye de yeşil ışık yakmaktadır.

Yakup Kadri'nin fese bir anlam ve değer yüklediği ilk romanı 1928'de yayımlanan ve işgal altındaki İstanbul'u anlattığı Sodom ve Gomore'dir. Sodom ve Gomore romanında fese, işgal kuvvetleri subaylarının gözünden Türk-İslam sembolü, dolayısıyla işgale ve işgalcilere dolaylı bir başkaldırı anlamı ve değeri yükler. Yazar, Sodom ve Gomore romanında İstanbul'daki işgalci askerlerin fese, Türk-İslam olmanın bir şiarı olarak baktıklarını gösterir. Bu nedenle romanda fes, bir anlamda işgale karşı kültürel başkaldırının, işgali tasvip etmemenin sembolü olarak kullanılır. Yakup Kadri, diğer eserlerinden farklı olarak burada fese tahammülsüzlüğü işgal ordusunun subayına yaptırarak onu dolaylı da olsa olumlar.

...o dik bakışını üzerinde saplanmış tutan adamın, yüzünde hiçbir hareket olmaksızın, hatta ağzı bile kımıldamaksızın kendisine İngilizce bir şey bağırdığını gördü. Zavallı Türk gencinin yüzü sapsarı kesildi ve Fransızca olarak:

- Ne söylüyorsunuz, anlamıyorum' dedi.

İngiliz, yine o taş gibi donmuş vaziyetini bozmadan, ağzı kapalı, aynı sözü tekrar etti... Bunun üzerine ikincisi... şu cümleyi heceledi:

- Dostum Captain Winter, başınızdan fesinizi çıkarmanızı istiyor.

Necdet hayretle baktı:

- Ne hakla? Lütfen sorar mısınız? dedi.

Tercümanlık vazifesini üzerine alan İngiliz sanki Necdet'i ısırmak istiyormuş gibi çenesini öne doğru uzattı:

- Dostum Captain Winter sualinize 'Bir galip hakkıyla! Cevabını veriyor’ dedi. (Karaosmanoğlu, 1996: 88-89)

1949'da tefrika halinde yayımladığı Panorama adlı romanında ise Tahıncızâde Hacı Emin Efendinin şapkaya bakışı ve tavrı üzerinden bir zihniyeti resmeder. Daha doğru bir ifade ile sadece resmetmekle kalmaz, kendi dünya görüşü üzerinden bir kesimi adeta ötekileştirir. Cumhuriyetin ilk yıllarından Demokrat Parti'nin iktidara geçtiği ilk yıllarına kadarki zaman dilimini ele alan bu eserin ilk sayfalarında yeni devleti, "herkesin şapka giydiği, sakal ve bıyıklarını tıraş ettiği” şeklinde tasvir eder (Karaosmanoğlu, 1983: 39). Bununla birlikte Yakup Kadri, şapkanın ruha değil "kelleye" geçirildiği kanısındadır. Şapkanın bir zihniyet nişanesi, kendisini aşan bir "mana"sının olduğu inancındadır. Bu nedenle romanında "birer tarihi vakıa olarak bunların kıymeti nedir?” (Karaosmanoğlu, 1983: 39) diye sorarak düşüncelerini tartışacak zemin hazırlar. 
Festen şapkaya geçmenin, kavuğu atıp fesi giymekten daha büyük bir ehemmiyeti mi vardır? Tanzimatçı dedelerimiz de tepeden tırnağa kıyafet değiştirmişlerdi; sakal ve bıyıklarını o devrin Avrupa modasına göre kesip taramışlardı... Lakin bütün bunlar, elli altmış yıl sonra bir yeniçeri kıyamından farkı olmayan 31 Mart'ları bir Kabakçı Mustafa isyanından ayırt edilmeyen Babıali baskınlarını önleyebildi mi? (Karaosmanoğlu, 1983: 39-40)

Yazar şapkaya karşı olanları Tahıncızâde Hacı Emin Efendinin şahsında adeta karikatürleştirerek ele alır. Şapka kanunu çıktığı günden beri evinden dişarıya ayak atmayan Tahıncızâde her devre uyan, hatta işgal zamanında düşmanla bile hoş geçinmesini bilen biridir (Karaosmanoğlu, 1983: 41). Fakat iş fesi çıkarıp şapka takmaya gelince "sabır ve tahammülü”" taşar. Tahıncızâde şapka kanununun çıktığı "uğursuz” anı bir "felaket”" gibi anımsar. Roman boyunca karşılaşılan Tahıncızâde, olabildiğince olumsuz bir tip olarak ve her bölümde şapka özelinde vurgulanarak ele alınır. Yıllarca şapka takmamak için "kendi evinin çatısı altında diri diri gömülmek" pahasına dışarı çıkmaz. Tahıncızâde'nin şapka kanununa bakışı da muhalif çevrelerin bakışını yansıtır.

Bir devletlinin keyfi istemiş, ehl-i İslam’ı karnavala çevirmeye kalkışmış. Biz de buna olmaz demişiz. İşte günahımız bu. Yahu, buraya gelen elin gâvuru bile bize böyle bir hakareti reva görmediydi. (Karaosmanoğlu, 1983: 359)

Burada da şapka dinî bir söylem kullanılarak reddedilmektedir. Tahıncızâde’nin Demokrat Parti iktidarından beklediği de şapkanın kaldırılıp yerine fesin getirilmesi ve Arapça ezan okunması gibi değişimlerdir.

Hani 'şer-i şerifi' yavaş yavaş getirip, 'ehl-i İslam'ı' bu perişanlıktan kurtaracaktı? Kaçgöç, şapka, fes meselelerini halletmek şöyle dursun, daha şu Türkçe ezan kepazeliğinin bile önüne geçemedi. (Karaosmanoğlu, 1983: 389)

\section{YAPILAN İNKILÂPLARA GÖRE ŞEKİLLENEN EDEBİ ANLATIM: REŞAT NURI'’NIN ROMANLARINDA DEĞISSEN DEĞER YARGILARI}

Reşat Nuri'nin romanlarında, yayımlandıkları yıla bağlı olarak, fes ve şapka motifi farklı anlamsal değerlerde yansır. Şapka kanunundan önce yayımlanan Gizli El, Ateş Gecesi gibi romanlarında şapka ötekinin ve toplumsal değerlerden kopuk olanın; fes ise -olumlayıcı bir bakışla verilmese de- kimliğin, toplumsal uyumun sembolüdür. 1928' de yayımlanan Yeşil Gece romanında ise fes ve sarık "yobazlığın, gericiliğin” işaretleri olarak yer alır.

Reşat Nuri'nin Gizli El romanı, şapka kanunundan 1 yıl önce yayımlanır ve şapkayla ilgili ilgi çekici bir diyalog içerir. I. Dünya Savaşı'nın hemen öncesiyle 1920'ye kadar geçen süreyi kapsayan olayların anlatıldığı romanda şapkayla ilgili kısım da savaşın hemen öncesinde, yani tahminen 1913 yılında, Aziz Beyin çiftliğinde geçen bir konuşmada görülür. Aziz Beyin çiftliğine kalabalık bir akraba grubu gelir. Döneme göre gayet "alafranga" olan bu akraba grubun içinde Nevnihal Hanım, yaşayışındaki sivriliğiyle ön plana çıkar. Aziz Beyin oğluna özel ders veren Şeref' in gözlemlerinden aktarılan sahne şöyledir: 
Demek ki, Nevnihal Hanım kendisiyle böyle şakalar yapılabilen fazla alafranga bir kadınd1. Nasıl ki biraz sonra söz arasında onun da epeyce bir zaman Avrupa'da yaşadığını ve hattâ şapka giydiğini söylediler ... ${ }^{9}$ Hanımefendi, bunu da sordu:

- Ulûm-i diniye hocasına soracaklarımdan biri de bu... Şapka da şarap gibi haram mıdır, değil midir? Hele kadın için?..

- Ne münasebet efendim, dedim, hatta en kaba sofu hocalar bile: 'Güneşin yahut yağmurun ve soğuğun başı hasta etmesi gibi bir tehlike varsa, şapka giymekte beis yoktur' derler. Maamafih, bunu da yine Doktor Beye havale edeceğim. (Güntekin, 2016: 62-63)

Olumsuz çizilen Nevnihal Hanımın aşırıya kaçan tarafının şapka üzerinden ifade edilmesi, şapkanın yapılacak kötülüklerden adeta sonuncusu olarak vurgulanması o dönem insanının şapkaya bakışını ele veren önemli bir örnektir.

Vaka zamanı Gizli El ile aynı dönemde geçen Yeşil Gece romanında ise fes ile sarıklı ayrımı daha ön plandadır. Hatta Yeşil Gece, sarık ile fesin çatışması üzerine bina edilmiştir denilebilir. Burada ilginç olarak fes, simgesel değer olarak şapkanın adeta yerini almıştır. Yani bu romanda "yenilikçiliğin" sembolü festir, "yobazlık” ise sarıkla sembolize edilir. Romanın başkişisi Şahin hoca üzerinden fes-sarık mücadelesi ve çatışması verilir.

[Şahin hoca] Nuruosmaniye'de eski ders şeriklerinden Zeynel hocaya rast geldi. Somuncuzade medresesinde dört sene arkadaşlık etmişlerdi. Zeynel hoca, Karadenizli koyu mutaassıp bir softaydı... Zeynel hoca, Şahin Efendinin sarığı çıkarmasını affedememişti. Onu görünce 1sırmaya hazırlanmış yırtıcı bir hayvanın dişlerine benzeyen sivri, uzun dişleriyle güldü:

- Hepsi tamam hocam. Bir şapkan eksik kalmış, dedi. Şahin Efendi, kalender ve şakacı tavrıyla:

- O da olur inşallah, dedi. Anadolu'dan sarıkla geldim, fesle gidiyorum, bir zaman belki şapkayla dönerim ama sen göremezsin. (Gültekin, 2015: 10)

1928 yılında yayımlanan Yeşil Gece'deki bu alıntıda aslında medreselilerin fese de olumlu yaklaşmadıkları ve şapkaya giden yolda geçici bir durak nazarıyla baktıklarını görürüz. ${ }^{10}$ Aynı zamanda ruhsal ve düşünsel değişimler geçiren Şahin Efendinin de bu değişimlerinin kıyafetine, başlığına yansıması konumuz bağlamında önemlidir. Bilinçli bir tercih ve bu tercihin göstergesi olarak sarık çıkarılıp fes takılmış; ayrıca şapkaya da yeşil ışık yakılmıştır. Dolayısıyla zihniyetin değişiminin de öncelikle başlıktan başladığını ve zihniyet mücadelesinin başlıklar üzerinden verildiğini görürüz. Başlık, zihinsel bir sınıflamanın keskin ayrımlarını sunmaktadır. Romanda yer alan medrese/okullardaki öğrenciler arasında da kutuplaşmalar, zihniyetlerini temsil eden başlıklara göre şekillenir.

9 Vurgulamalar bana aittir.

10 II. Mahmud'un da fesi şapkaya geçiş olarak gördüğü yönünde yorumlar vardır. 
Mektepte medreseden gelen sarıklılarla fesliler arasında bir anlaşmazlık vardı. Softalar, sivil mekteplerden gelen talebeyi çekemiyorlardı. Onlar da sarıklıları taassupla, irtica ile itham eder, olur olmaz bahanelerle softalara çatarlardı. Hatta bazen iki taraf arasında boğaz boğaza kavgalar bile oluyordu. Şahin Efendi, bu zümre ihtilâflarına hiç yanaşmadı. Softalardan ağzının payını almıştı. Öte tarafa karşı gerçi daha fazla bir yakınlık hissediyordu. Fakat başındaki sarıkla onların arasına karışmaya çekiniyor, bunun bir riyakârlık gibi görülmesinden korkuyordu.

Bu sarık meselesi Şahin Efendiyi en çok düşündüren bir şeydi. Medrese ile alâkasını kestikten ve itikadını kaybettikten sonra artık sarık sarmakta devam etmesine sebep kalmıyordu. Fakat iki şey onu düşündürüyordu: Babası onun hoca olmasını istemişti. Sarı̆̆ı atmak onun hatırasına hürmetsizlik olmayacak mıydı? Sonra, sırtına giyecek temiz bir elbisesi yoktu.

Ahali, hocaları sefil ve gülünç kıyafetlerde görmeye alışmıştı. Fakat baştan sarığı atarsa bu elbiseler, bu pabuçlarla talebeden ziyade dilenciye benzemeyecek miydi? Bu iki sebep Şahin Efendiyi iki sene daha sarıklı gezmeye mecbur etti. (Gültekin, 2015: 37)

Şahin Efendinin atandığı Sarıova normalde "irtica”nın en çok taraftar bulduğu yerlerdendir. Şahin Efendi bu nedenle tayinini Sarıva'ya özellikle ister. Eski bir medreseli, sarıklı olarak bu zihniyetle çok iyi mücadele edebileceğine inanır. Şahin Efendinin ilk gözlemlediği de başlıklardır. Çünkü başlıklar kimlerle ve kaç kişiyle mücadele edeceği hakkında ona ipucu verir. Şapka Kanunu çıkmasından hemen önceki iki farklı zihin dünyası fes ve sarık üzerinden verilir.

Sokaklar gibi bu büyük sofrada da müthiş bir sarıklı bolluğu vardı. Belediye reisinin sağında mutasarrıf Aziz Bey, solunda şal yelekli ihtiyar bir müderris oturuyordu. Başka yerlerde olduğu gibi sarıklılar bir araya toplanmamışlar, feslilerin arasına dağılmışlardı. İdadi müdürü, Şahin Efendiye bunu göstererek dedi ki:

- Sarıkla fesin uzlaşamayacağını söyleyenler bu manzara-i uhuvveti gördükten sonra acaba fikirlerini değiştirmezler mi? Ben, Galatasaray’da tahsil görmüş terakkiperver bir adamım ama hakikati söylerim. Sarıklılarla feslilerin din ve devletin selâmet ve itilâsı hususunda teşrik-i mesaisinden daima müfit neticeler beklenebilirdi. Yazık ki bu iki kardeş zümre arasına nifak sokuldu. (Gültekin, 2015: 46)

Yeşil Gece romanında fes-sarık ayrımının iki farklı zihinsel/ideolojik dünyanın çatışma ve çarpışma alanında yer edindiği de görülür. Şapka Kanunu'ndan sonra yazılması nedeniyle, bu romanda mücadele alanının ve sembolik değerlerin yeni rejimin arzularına göre yönlendirilmiş olduğu da gözden kaçırılmaması gerekir.

Sarığın ve dolayısıyla sarıklıların ayrıcalıklı bir sınıf teşkil ettiği ve bu ayrıcalıklı durumdan nemalanmak isteyenlerin varlığı da ayrı bir sorun olarak ortadadır. Anlaşılan sarığa duyulan bu hassasiyet, en azından bir kesim için, aynı zamanda kendi ayrıcalıklı konumlarının da korunmasıyla yakından ilgilidir. 
Bayrak, devletin; sarık, dinin timsalidir. Bayrağa hürmet nasıl bir borçsa sarığa hürmet de öyle bir borçtur. Maalesef bazı kuş beyinliler sarığa lâyık olduğu derecede hürmet etmiyorlar. Ancak, bütün kabahati onlara yüklemek doğru olamaz. Sarığın hakarete uğramasından ulema-yı kiramı da az çok mesul tutmak lazım gelir. Eline üç, beş arşın tülbent geçiren herkes fesine sarık sarıyor ve lazım gelen fazl ve kemâli iktisap etmek için hiçbir zahmet ihtiyar etmeksizin ulema sınıfına geçip oturuyor. $\mathrm{Bu}$, böyle devam edip gidemez. Mevcut sarıklılar arasında bir tasfiye yapmak doğru olmasa bile badema saracak olanları küçük bir imtihandan geçirmek iktiza eder. (Güntekin, 2015: 85)

Şahin Efendi Yunan'a esir düştükten sonra memleketine döndüğünde gözüne ilk çarpan şey de şapkalı erkeklerdir. Bu görüntüler onun tasavvurlarının kısa bir zaman içinde hakikat haline geldiğini göstermektedir.

Şahin Efendi, zaferden sonra hemen memleketine dönememişti... Biraz evvel arabayla ovadan geçerken tarlalarda geniş hasır şapkalı erkeklerin çalıştığını görmüştü. Hâlbuki on küsur sene evvel Sarıva'ya ilk gelişinde aynı yerlerde abani yahut yemeni sarıklı adamlar güneş altında ter döküyordu. Hâsılı, onun istediği ve düşündüğü şeyler tasavvurundan çok daha az bir zaman içinde hakikat haline gelmişti. (Güntekin, 2015: 215)

İşgallerin sona erdiği, istiklalin kazanıldığı, devrimlerin yapıldığı dönemde yenilik için bedel ödeyen Şahin Efendi ile yobazlığın Sarıva'daki en büyük temsilcisi, üstelik Yunan ordusuyla işbirliği içinde olan Eyüp Hocanın karşılaştı̆̆ı bölüm de yine fes-şapka-sarık üzerinden ele alınır. Fese bile tahammülü olmayan Eyüp Hoca melon bir şapka takmış ve sakalını tıraş etmiştir. Bu haliyle o, yazarın da vermek istediği gibi, aslında devrimleri ele geçiren yobaz zihniyeti ve devrimlerin nasıl ve kimler tarafından yozlaştırıldığını da gösterir.

Son olarak Reşat Nuri'nin 1942'de yayımlanan Ateş Gecesi romanında Osmanlı toplumunda fesli olmanın önemi, başı açık olmanın ayıp karşılanışının verildiğini görürüz. II. Abdülhamit döneminde Milas'a sürgün edilen on dokuz yaşındaki Kemal Murat, Çine çayından geçerken yanındaki eşyalar suya düşer. Eşyalarını kurtarmaya çalışırken fesi çayın akıntılarında kaybolur. Kendisine eşlik eden reji kâtibi "fesi kundura ve iç gömleği” kadar zaruri saymaktadır. Bu nedenle Kemal Murat'a başına bir mendil sarmasını söyler.

Çine çayı fesim gibi onları da alıp götürseydi halim ne olurdu?' diyordu. Fesi vücut için kundura ve iç gömleği kadar zarurî bir şey sayan reji kâtibi:

- Evlâdım, başına bir mendil sarıver bari diye akıl öğretmişti. Fakat o gözlerinin içi gülerek:

- Ziyanı yok beyefendi... Namaz kılacak değilim ki... Böyle de pekâlâ olur, diye cevap vermişti. Öyle görünüyordu ki, bu çocuk için, hiç olmazsa şimdilik 'pekâlâ' olmayacak şey yoktu. (Güntekin, 2008: 9) 


\section{SÖZÜNÜ YARIM BIRAKMIŞ BİR MÜTEREDDIT: HALİDE EDİP'İN INKILÂPLAR KARŞISINDAKİ KETUMLUĞU}

Halide Edip 38 yaşına kadarki hayatını anlattığı Mor Salkımlı Ev isimli anılarında ilk defa nasıl şapka taktığını, şapka takınca kendini nasıl hissettiğini anlatır. 31 Mart ayaklanmasında, kadınlar hakkında yazdıklarından dolayı, ülkeyi terk etmek zorunda hisseden Halide Edip bir gemiyle Mısır'a gider. "Bu arada ben de şahsen sık sık yazı yazdığım için mektuplarla hücumlara maruz kalıyordum. Bu imzasız mektuplar hep kadınların cemiyette bir mevki almalarına ve fikir sahibi olmalarına karşı şiddetle itiraz ediyor ve bunu dinimize mugayir addediyordu" (Adıvar, 2013: 139) Halide Edip' in Mısır' da olduğunu haber alan Isabel Fry, onu İngiltere'ye davet eder.

On beş gün için Kahire'ye gidip Ehramları gördükten sonra, Port Said'den yapayalnız, İngiltere'ye giden bir vapura bindim. Bana zor gelen şeylerden biri de o günlerde şapka giymek idi. ${ }^{11}$ (Ad1var, 2013: 154)

Şapka giymekte zorlanan Halide Edip'in çocukluğundan itibaren babasının tercihleri nedeniyle İngiliz terbiye usullerine göre yetiştirildiği ve onlar gibi giydirilmek istendiği de göz önünde bulundurulmalıdır. Yani şapka giymekte zorlanan Halide Edip, daha önce bu tür giyim kuşamı bilmeyen biri değildir. Buradan hareketle bile şapkaya yüklenen değer ve sembolü tahmin etmek kolaylaşır. ${ }^{12}$

Babası, İngilizlerin terbiye usullerini, çocuklarına giydirdikleri esvapları, verdikleri gıdayı kızına tatbik etmek istiyordu. Çoraplarından, pabuçlarından, mendillerinden,

11 Vurgular bana aittir.

12 Aslında kılık kıyafetle ilgili tek değişim fes-şapka bağlamında yaşanmaz. Halide Edip'in hatıralarında, özellikle "münevver kadın"lar arasında değişen giyim kuşamın izlerine şu alıntıda rastlarız:

"Evkaf mekteplerini eski mahallelerde teftişe gittiğim zaman, umumiyetle eski, uzun ve bol bir çarşaf giyer, yüzümü açık bulundururdum. Fakat, o sabah Arasta'dan geçmek ihtimali aklıma gelmediği için, biz yaştakilerin bu mahallelerin hoşuna gitmeyen modern kıyafetini muhafaza etmiştim. O dar sokakta bir alay kız çocuğu, aşağı yukarı piyasa ediyorlardı. Paramparça basma entarili, çıplak ayakları eski takunyalı, ağıları sakızlı, fakat sakızla birlikte kelimeleri de çiğneyerek birbirlerine lâf atan çocuklar. Bir tanesinin kucağında, kendisinin yarısı kadar bir çocuk. Bir tanesinin elinde -muhakkak çalmış olacak- bir şık şemsiye, o günün sosyete hanımlarını taklit ederek kırıtıyor, süzülüyorlardı. O günün münevver sayılan kadın sınıfının bu kadar gülünç olduklarını ancak bu çocukları görünce anladım. Anlaşılan o sokağa kendi meskûnlarından başka pek kimse girmiyordu. Beni görür görmez hemen taklide ve alaya başladılar. Şemsiyelisi bağırarak diyordu ki: — Bak, bak başında bir kazan -saçımın tepeme toplanmış olması- arkasında bir peştamal -bu da çarşafın darlığına işaret- Hah, hah, hah. Birdenbire hepsi beni taklide, bağırarak bana söz atmaya başladılar. Bu bana realist bir komedi parçası gibi geldi. Mümkün olsaydı modaya uygun çarşafı atar, ayaklarıma takunya geçirir onların alaylarına iştirak ederdim. Fakat bunda alaydan başka bir de tehlike işareti vardı. Yani çarşafımı parçalamaya, beni taşlamaya hazır oldukları yüzlerindeki hınç ifade eden ışıltıdan belli oluyordu...

Biz, sokağın sonuna kadar -ben sırtımı duvardan ayırmayarak- kaymıştık. Bu gürültüyü duyan ve kalabalığı gören bakkal ve kasap ellerinde birer sopa ile imdadıma geldiler. Kalabalık onları görünce çığlık atarak dağıldı. Kasapta Ortaçağ'da bir kadın kurtaran şövalye gururu vardı.

— Bu sokaktan bu kıyafetle geçmeyin ha. Ben birçoğunu taşlanmaktan kurtardım.

Kasabın bu iddiası belki de böbürlenmekten ibaretti. Fakat tavsiyesi pek yerinde idi. Fatih, Cihangir ve Kasımpaşa'da yüzüm açık, bol ve eski bir çarşafla dolaşırken, çocuklar etrafımı alır bana yol gösterir, 'hanım teyze,' diye bana sokulurlardı." (Adıvar, 2013: 193-195) 
hulâsa her şeyinden o mesuldü. Yalnız şapka giydirmek, o günler için mümkün olmadığından çocuğu yazın başı açık gezdiriyor, kışın da kalpak giydiriyordu... Onu tazip eden şey kendi yaşında ve kendi sınıfına mensup çocukların kıyafetlerinin bambaşka olması idi. (Adıvar, 2013: 27-28)

Halide Edip hatıralarında fesle ilgili de ilginç bir bilgi paylaşır:

“'Bosna-Hersek'in işgalinde, Türkiye'de Avusturya malları boykot edilmiş, fesler umumiyetle Avusturya malı olduğu için, herkes fes yerine yerli başlıklar giymeye başlamıştı. Tabiî bu, yerli fes fabrikaları açılmaya sebebiyet verdi.” (Adıvar, 2013: 163)

Halide Edip'in romanlarında da takılan başlıkların sembolik değerlerler taşıdığı görülür. Romanlarında Osmanlı'nın son dönemleriyle Cumhuriyet'in ilk yıllarında yaşanan olaylara yer veren Halide Edip'in anlatımında Şapka Kanunu'yla ilgili duygularını belirleyebilmek, Reşat Nuri ve Yakup Kadri'den farklı olarak, pek de mümkün değildir. Bunun nedeni olarak o dönemde ülkede olmaması gösterilebilir.

Halide Edip'in ilk olarak 1936 yılında yayımlanan ve II. Abdülhamit döneminde geçen olayların anlatıldığı Sinekli Bakkal romanında başlıklar genel olarak dinî/mezhebî farklılıkların alamet-i farikası olarak kullanılır. Romandaki farklı medeniyetlere ve dinlere mensup iki önemli kişi, Peregrini ile Vehbi Dede'nin taktıkları başlıklara özellikle bu türden bir kimlik alameti olarak dikkat çekilir. Yıllarca Müslümanlar arasında yaşayan Katolik dünyasının aforoz ettiği Peregrini başında şapkasıyla tasvir edilir, bu kıyafetinden dolayı bir “öteki” algısı oluşturulur ve yine kıyafeti, karşısındakinin gözünden, garipsenerek verilir.

Siyah harmanili, üç köşeli kocaman şapkalı, kısa boylu, çevik tavırlı bir ecnebi idi. Sinekli Bakkal civarı Hıristiyanları şapka giymedikleri için Rakım, bunu bambaşka, Beyoğlulu bir müşteri, belki de bir seyyah olarak teşhis etti. (Adıvar, 2013: 85)

Bir müşteri olarak geldiği "fakir ve orta halli” bir semtte Peregrini, ilk olarak kıyafetiyle algılanır ve kıyafetinden hareketle bir kimlik analizi yapılmaya çalışılır.

Rakım güllaçları sararken birdenbire kaşları çatıldı. Herifin kıyafetiyle güllaç arasında bir münasebet yoktu. Sonra kıyafetiyle söylediği Türkçe arasında da bir münasebet yoktu. O halde? Yoksa herif bir hafiye miydi? Bazen tebdil-i kiyafet de gezdikleri söyleniyordu. (Adıvar, 2013: 86)

Bu romanda da şapkanın, "küfrün” yani ötekinin göstergesi, hatta "en hususi alemi” olarak algılandığını görürüz. Peregrini’nin “öteki” olarak görülmesinin nedeni kafasındaki şapkasıdır. Bunun farkına varan/farkında olan Peregrini de öteki algısını yıkmak için kafasındaki şapkayı çıkarır.

Rakım'ın gözleri zihninde küfrün en hususi alemi olan üç köşeli şapkaya kaydı. Cemaat ibadet ederken ecnebi ziyaretçilere alışık değildir. Rakım'ın gözlerinin istikametini takip eden Peregrini başından şapkasını çıkardı yere attı. 
- Ben şapkasız giderim. Evde bir fesim var. Hem bir daha bu mahalleye şapkalı gelmeyeceğim. Ben dinî hislere çok hürmet ederim... Ben, ben vaktiyle bir nevi derviştim. (Adıvar, 2013: 87)

Süleymaniye Camii'nde mukabele okuyan Rabia'yı dinlemeye giden Peregri'nin fesli olarak tasvir edilmesi de, romanın sonunda İslam'ı seçecek olan Peregri'nin yaşayacağı medeniyet değişiminin ipuçları olarak okunabilir.

Rabia'yı dinleyenler arasında Peregrini ile birlikte Vehbi Dede de vardır. İki farklı medeniyetin temsilcisi olarak resmedilen Peregrini ile Vehbi Dedenin bulunduğu ortamda Rabia’nın “İki Şarkın Rabbi... İki Garbın Allah’ı” ayetini okuması da anlamlı bir tercihtir. Yazar, Peregrini ile Vehbi Dedeyi adeta taktıkları başlıklarla bir sınıflamaya tabi tutar, bu şekilde iki farklı dünyaya oturtur.

Perdenin önündeki iskemlelerin birinde dâimâ başına küçük gelen fesiyle Peregrini oturur, arkada, hasırın üstündeki çocuk alayı arasında Vehbi Dede’nin uzun külâhı görünürdü. İkisi de sallana sallana gülerlerdi. (Adıvar, 2013: 96)

Bundan ayrı olarak, bu romanda, fesin tek tip bir başlık olmadığı ve çeşitli sınıfları, sosyal statüleri işaret ettiğini görürüz.

Köpek herifin lanetli fesi, dünyayı ürküttü.

- Kim olduğunu biliyor musun, Ağabey?

- Fesinden kim olduğunu anladım. Burada ne sordu? Rabia da nihayet anlamıştı. Uzun kırmızı feslerin hafiyelere alâmet olduğunu işitmişti. Fakat Sinekli Bakkal'da onlara benzer adam görmediği için unutmuştu. (Adıvar, 2013: 141)

Cumhuriyetin ilk yıllarından konusunu alan ve 1939 yılında yayımlanan Tatarclk romanında ise Şapka Kanunu'nun topluma izdüşümünü görmek mümkündür. Sadece üç yıl öncesinde, henüz Avrupa'dayken, yazdığı Sinekli Bakkal'da Peregrini'ye fes giydirip Müslümanlaştıran Halide Edip, artık şapkaya medeni bir sembol gözüyle bakıyor gibidir. Romanda yer alan kişileri başlarında şapkayla tasvir eder. Kişilerde şapka giyme âdeti artık yerleşmiştir. Bu tasvirlerde övgü ve yergiden uzak durur; ama genel hatlarıyla bakıldığında olumsuzlayan bir bakış yoktur. Romanda verildiği kadarıyla şapka, toplumsal davranışlara yansır.

Bir türlü Lâle'ye iltihak edemeyen, kalabalığın içinde Recep'in yardımıyla geçirilen genç bir Amerikalı kadın iskeledeki sahneyi, Amerikanvari bulmuş olacak ki, kahkaha kahkaha üstüne atıyor, bir düziye, "Oh how jolly!" diye haykırıyordu. Nihayet Miss Barkley 'İşte dostum,' der demez Recep gülerek:

- Să̆ salim teslim ediyorum... Şapkam olmadığı için selâmlayamıyorum, affedin bayan, demişti. (Adıvar, 2009: 58) 
Son olarak Zeynonu'nun Oğlu romanında bu bağlamlardan daha farklı bir kullanımla karşılaşırız. Bu romanda, baloların anlatıldığı bölümlerde, kıyafetle zihniyet arasında bağlantılar kurulmakla beraber, romanda olayların geçtiği dönemde henüz Şapka Kanunu çıkmadığından şapkayla ilgili bir şeyler yoktur. Sadece romanın başkişilerinden Haso belli bir yaşa eriştiğinden dolayı fes giymeye başlar. Bu aktarımdan fes ve takkenin aynı zamanda kişilerin yaşıyla da bağlı bir gelenek olduğu anlaşılır ve elbette bir de hangi yaşta olursa olsun erkeklerin başında mutlaka bir başlık olduğunu belirlemek mümkündür.

Bu sabah, heyecanı bol bir sabahtı. Haso çocuk, yeni bir şalvar, yeni bir mintan ve başına ilk defa Şaban amcanın aldığı kırmızı yemeni sarılı püsküllü bir fes giyecekti. Bugün Haso, takke devrinden fes devrine geçiyordu. Gerçekten bütün bu iyi şeyler biraz merakla beklediği babanın şerefine idi. Fakat asıl sevinci, daha çok, bu ilk fes içindi. (Adıvar, 2006: 60) (13 $^{13}$

\section{DOĞU ÍLE BATI ARASINDA MED-CEZİR: PEYAMI SAFA'NIN PARADOKSU}

İlk romanını Cumhuriyetin ilan edildiği 1923 yılında yayımlayan Peyami Safa, Şapka Kanunu'nun ilan edilmesinden iki yıl kadar önce yazdığı, Mütareke döneminde geçen olayları konu edinen Sözde Kızlar romanındaki bir cümleyle o dönemde toplum nezdinde fes takmanın ne kadar gerekli olduğuna vurgu yapar. Romanın kahramanlarından Salih bir muharriri anlatırken; "Fessiz sokağa çıkar, kadınsız çıkmazdı. Yaman çocuktu.” (Safa, 2016: 38)

I. Dünya Savaşı döneminde geçen olayları konu edindiği Mahşer romanında da başkarakter Nihad üzerinden dönemin fes hassasiyetini birkaç cümleyle verir.

Aksaray’a doğru yürüdü, sonraya geriye döndü. Hep hızlı hızlı gidiyordu. Bu serin havaya ihtiyacı var. Birden elini başına götürdü: O ne? Fesi yok! Fessiz çıkmış. Cinnet! Herkes bakıyor. Rezalet! Bir fes lazım. Bir dükkâna girdi, hasırlı hazır feslerden birini başına geçirdi. Fakat bunu niçin giyiyor? Ne lüzum var sanki? Bilmiyor. (Safa, 1996: 293)

$\mathrm{Bu}$ cümlelerden hareketle Osmanlı toplumunda bir erkeğin fessiz, yani başı açık dışarı çıkmasının toplum nezdinde ne kadar kötü karşılandığ 1 ve fertlerin bu "mahalle baskısı" karşısında psikolojik kabullenmişliği görülür. Bu zorunluluğa duyulan rahatsızlık da ayrıca anlatımda sezdirilir. Denilebilir ki, fese karşı olmasa da, bir başlığın takılmasına duyulan rahatsızlık vardır.

İlk olarak 1933 yılında yayımlanan, Cumhuriyet'in ilk yıllarında geçen bir olayı içeren Bir Tereddüdün Romanı adlı eserinde de başlıklara sembolik bir değer ve anlam yüklenir. Fes

13 Anılarında ve romanlarında kıyafetle zihniyet arasında ilgi kurduğunu gördügüümüz Halide Edip'in romanlarında konuyla ilgili fazla bir şey bulamamamızın nedeni muhtemelen Şapka Kanunu çıktığı dönemde Türkiye'de olmamasıdır. Bununla birlikte Türkiye'deki inkılap hareketlerini yakından takip ettiğini bildiğimiz Halide Edip'in suskunluğunun tek nedeni bu olmasa gerek. 
ve şapka bu alıntıda zihniyet farklılığının sembolüdür. Romandaki başkişilerden Vildan'a şunlar söyletilir:

“Ben bu dünyada Lâtin ve Grek’ten başka medeniyet yapan unsur tanımıyorum. Fakat beni gene körü körüne bir garp medeniyeti âşı̆̆ı zannetmeyiniz. Sizin şarkı anlayışınız hoşuma gidiyor. Garp valörleriyle şarka bakıyorsunuz. O vakit Asya yeni bir cazibe altında görünür. Sarığın değil, şapkanın altında Asya' ya bakmak yeni bir şey. Fakat şarklı olmak şartıyla. Bizim gibi.” (Safa, 1998: 82)

Romanları haricinde düşünce kitaplarında da değindiği kıyafet ve zihniyet ilişkisi Safa'nın konu hakkındaki düşüncelerini öğrenmek açısından önemlidir. Konumuz bağlamında Türk Ínkılabına Bakışlar adlı eserinde önemli veriler sunar. İttihat ve Terakki yönetiminin 1916' da "garpçıların programını tatbike" başladığını belirten Safa'nın saydığı bu birkaç tatbikten biri de şapkanın "müjdecisi” sayılan Enveriye isimli başlıktır. "Orduda biraz şapkayı andıran ve 'Enveriye' adını alan bir serpuş nev’i de ihdas edildi. Garpçılar bu acayip külâhı şapkanın bir müjdecisi telakki ediyorlardı.” (Safa, 2010: 45)

Oysa Safa eserinde bu türden "yarımlık”ları milletin başına bütün belaları üşüştüren sebep olarak görür. Bu türden yarım kalmış inkılaplar; "Türk bünyesini hem şark ve garp, hem din ve milliyet arasında yarımşar ve sakat iki parçaya bölüyordu.” (Safa, 2010: 54)

Şapka Kanunu'nu Atatürk'ün "Medeniyetçilikten doğma inkılâp hareketleri” arasında sayan Peyami Safa, Atatürk'ün “büyük bir ameliyat” yaparak bu türden tüm ikilikleri kaldırdığını söyler. Enveriye'den şapkaya geçişi de bu türden tamamlayıcı, bütünleyici inkılaplardan sayar. "Atatürk bu büyük ameliyatı yaptı. Türk bünyesinde yaşamaya müsait gördüğü bu iki fikrin Osmanlılık mefhumuna yapışan ölü taraflarını kesip attı. Artık Tanzimat'ın yarı şerî, yarı nizamî mahkemesinden eser kalmayacaktı; artık Türk maarifi yarı mektep, yarı medrese içinde bilgi dağıtmayacaktı; artık Enveriye, şu bu gibi yarı şapka, yarı külah acayip serpuşlar aranmayacakt1." (Safa, 2010: 53)

\section{SON SÜRGÜNÜYLE SUSKUNLUKTA SELAMET BULAN EZELI MUHALIF: REFIK HALIT'TE KEKEMELI ANLATIM}

Milli Mücadele'nin başarıya ulaşmasından sonra vatandaşlıktan çıkarılan 150'liklerden biri olan Refik Halit, ilk gençliğinden itibaren sivri diliyle iflah olmaz bir muhaliftir. 1938'de genel af ilan edilinceye kadar Lübnan ve Suriye'de yaşamak zorunda kalan Refik Halit bu aftan faydalanarak Türkiye'ye döner. Bahsi geçen genel affın çıkarılmasına sürgünde yazdığı Deli isimli eserin etkili olduğu Yakup Kadri tarafından ifade edilir. ${ }^{14}$ İnkılapların yapıldığ 1 dönemde ülkede bulunmayan Refik Halit, bu eserinden de anlaşıldığı kadarıyla, Türkiye'nin

14 Yakup Kadri Gençlik ve Edebiyat Hatıraları adlı eserinin "Refik Halit” bölümünde konuyla ilgili detaylı bilgiler verir. Atatürk'ün Refik Halit' in yazılarını okuyup duygulandığını, birkaç zamandır gönlünde taşıdığı af arzusunun kanun haline getirilmesinin de Refik Halit'in Deli adındaki eseri nedeniyle olduğunu belirtir (Karaosmanoğlu, 1969: 87). 
gündemini yakından takip etmiştir. Şapka Kanunu çıktığında ülkede olmamasına rağmen diğer inkılaplarla birlikte şapka giyilmesini öngören kanunun yaşattığı toplumsal şoku bu eserinde işler. Bununla birlikte ülkeye döndükten sonra kaleme aldığı romanlarında bu konularda ketum davranır. Deli isimli eserinde Cumhuriyet'in ilanından önce felç geçiren birinin yıllar sonra bilincinin yerine gelmesiyle karşılaştığı durumlar neticesinde yine aklî dengesini kaybetmesi konu edinilir. Eserin başkişisi Maruf Bey’in iyileşmesinden sonra kendisini Yakup Hoca adında eski bir dostu ziyaret etmek ister. Maruf Bey, bu medreseli eski dostunun şapka taktığını duyunca tepkisi "Demek Yakup Hoca tasannur da etti... Vay Kâfir vay!” (Karay, 2014b: 17) şeklindedir. Kendisine bu bilgiyi veren Şebnur Kalfa ise durumu “zamaneye uymak" şeklinde izah eder. Üstelik fes ve sarığın yasak olduğunu, fes veya sarıkla gezenleri yakaladıkları gibi karakola tıktıklarını ve en aşağı üç ay hapis yatırdıklarını söyler (Karay, 2014b: 18). Dışarıdan gelen müzik sesinden askeri bir geçidin olduğunu anlayarak dışarı bakar ama askerlerin şapka giydiklerini görünce onları "Moskof askeri” sanır. (Karay, 2014b: 30)

Yazarın Yezidin Kızı adlı romanında ise kıyafet kanununun sonucuna iğneli bir gönderme yapılır. Kanunun gereğini yerine getirirken acayip bir görüntü oluşturanlara dikkat çekilir.

Bu sırada merdiven başında acayip bir tip belirdi: Sakalı kapkara, kocaman, bukle bukle bir adam... T1knaz, omuzlu vücudunu cüppe veya redingot, ne olduğu birden anlaşılamayan siyah, bol bir elbise kaplamış. Türkiye'de klyafet kanununa uyan hocalara ve papazlar benziyor ama kadın yayvan vücuduyla ve enli, itinalı, kıvırcık, taranmış değil işlenmiş sanılan sakalıyla operet uydurması bir Asuri kâhinini daha çok andırıyor. (Karay, 2009a: 8)

Fes ve şapkaya sembolik değerlerin yüklendiği dönemleri yaşayan Refik Halit Bugünün Saraylısı romanında ise şapkayı yeni bir yaşam ve düşünce biçiminin yani zihniyetin göstergesi olarak ele alır. Romanın başkişilerinden Ata Efendinin “eski değerler” sistemindeki düşünceleri karşısında eşi Ferhunde Hanımın söylediği sözler, şapkanın zamanın ruhuyla ve dönemin yeni değerleriyle özdeşleştirildiğini gösterir.

"Başına sımsıkı geçirdiğin şapkana dinletiyorum. Şapkalı kafanı zamaneye uydur, efendi." (Karay, 2014a: 55)

Ortadan kalkan eski konak yaşantılarına şahit olan nesli anlattığı ve dolayısıyla eski ile yeniyi karşılaştırabildiğimiz Bu Bizim Hayatımız romanında da şapka-zihniyet ilişkisi ve eskilerin başı açık bulunmaktan imtina etmelerine birer gönderme yapılır.

Ey, şimdi ne yapacağız? Anladığıma göre nüfus kalemine gideceğiz. Kâtip Gazanfer' i dışarıya çağırtalım da işi anlatıver. Ben daireye girmem adama kasketini çıkartıyorlar. Hamdolsun kelim yok ama baş açık durmak istemiyorum, işte! Kuşlar da kasketime alışmışlar; çıkardım mı yabancı sanıp çırpınıyorlar, elime konmuyorlar. (Karay, 2009b: 109) 
Zihniyet değişiminin kıyafetle mümkün olmadığgna da yine yüzeysel bir değiniyle işaret eder.

Hayatının büyük kısmını Avrupa'da geçirmişler için oradakileri yalnız bizim yerli kadın tiplerimiz yeter derecede hatırlatamazlar. Şapka ve garp kıyafeti de yetmiyor. Pek güzel olabilirler; lakin anlayan onları bazı 'nüans'lardan dolayı öbürlerinden ayırır. Biraz da sıcakkanlı, cana, bizim canımıza yakın oluşlarından; belki de erkeğe başka türlü bakışlarından; erkek muhitinde az çok iğreti duruşlarından; ne kadar göstermeseler kumru gibi bir hal alışlarından! (Karay, 2009b: 228)

\section{HER OTORITEYE BAŞKALDIRI: KEMAL TAHIR'DEN GERÇEKÇİ MÜŞAHEDELER}

1910 doğumlu olan Kemal Tahir, Şapka Kanunu çıkarıldığında ancak on beş yaşındadır. Yani bu makalede ele aldığımız yazarlardan bir tek Kemal Tahir bu kanunun çıkmasından önce herhangi bir eser yazmış değildir. Bununda birlikte Kemal Tahir'in eserlerinin birçoğunda, ele aldığı dönemin de etkisiyle, fes-şapka çatışmasının sembolik değerler atfedilerek kullanıldığını görürüz. Ayrıca; festen şapkaya geçildiği tarihte bu değişimi gözlemleyebilecek yaşta olması da Kemal Tahir'i burada ele almamız gerektiğini düşündürdü.

Esir Şehrin Insanları'nda Kamil Bey ile Nedime Hanım arasında geçen konuşmada şapka üzerine de muhabbet edilir. Bu konuşmadan her ikisinin de şapkadan yana olduğu, dolayısıyla karşılarında ölüm-kalım savaşı verdikleri Avrupa'nın kültürünü benimsedikleri görülür. Kamil Bey, kendisinin de eşinin de Avrupa' dayken şapka taktıklarını ifade eder; ama burada buna imkân bulunmadığını belirtir. Nedime Hanım da "şimdi burada kostüm tayyörle" olmak istediğini ve şapka takmayı arzuladığını söyler. Bu sözler Kamil Beyi çok şaşırtır.

- Şapka mı? Siz neler söylüyorsunuz? Yobazlar, topuklardan dört parmak kısa etek giyen kadınların çarşaflarına kezzap döküyorlar.

- İyi ediyorlar. Başka türlü bizi başkaldırmaya zorlayamazlar.

- Gerçekten, şapka ile sokağa çıkmaktan korkmaz mısınız?

- Hiç... (Tahir, 2005a: 170)

Nedime Hanım ile Kamil Beyin konuşmalarından değişimin, mevcut düzenle mücadelenin, savaşımın giyim kuşam üzerinden başlatılmak istendiği anlaşılır. İlk ve en anlamlı cephe kültür ve medeniyet değişimini imleyen dış görünümdür. Nedime Hanımın ifade ettiği "Bir fikir kadınlar tarafından kolayca kabul edilirse o fikir er-geç, yüzde yüz yener” sözleri de anlamlıdır.

Şapkaya karşı bir tavır da Hür Şehrin Insanları'nda görülür.

Ziya'nın babası Hacı İsa Efendi, burada yazmacılık yapıyordu. Uzun boylu, zayıf her zaman hiddetli bir adamdı. Şapka Kanunu'ndan sonra ilahiyat Fakültesi'nden istifa etmiş, burada yazmacılığa başlamıştı. (Tahir, 2010a: 162) 
- Milleti mutaassıp sanırdık. Meğer yobazın iftirasıymış. Şapkayı giydi. Biraz homurdandı ama giydi. Çünkü yüz sene evvel fes için de bilmeden homurdanmıştı. Yeni harfleri kabul etti. Biraz homurdand1. Lakin kabul etti. (Tahir, 2010a: 611)

Şapka giyilmesini zorunlu tutmayan, sadece başka başlıkları yasaklayan kanunun bu şekilde anlaşılmadığ 1 da yine aynı romandan anlaşılır.

- Enver mi? Hay beyim, görmeliydin! Refik Bey’e de böyle rica ettim. Dinlemedi. Biraz da keyfi galiba... Yukarı çıktı. Kapıya dayandı. Usulüyle içeri aldılar. Bir on dakika sonra bir feryat, bir gürültü... Koştum ki zavallı Refik Bey’i, karıyla bir olup bir güzel ıslatmışlar, başını yarmışlar. Palaskası, şapkası içerde kalmış. Yalvarmaya başladı. Nasıl yalvarmasın, kel herif “Merkez Kumandanlığına gideceğim!” diye ayak diriyor. Refik Bey’i görmeliydin beyim! Zabit ama, öyle acar zabit değil... Yalvarmasına ancak Kel Enver olmalı dayansın! 'Beni zabitlikten kovarlar, ocağınıza düştüm!' diyor. Nihayet araya girdim de... Şapkayı, kayışı alıverdim. Sonra iyileştiler. Gelir gider oldu. (Tahir, 2010a: 677)

Bir erkek için başı açık olmanın geleneksel olarak büyük bir ayıp şeklinde algılandığını Sağırdere'de görürüz. Yukarıda gösterdiğimiz üzere; diğer yazarların romanlarında da bu türden örnekler görülür.

- Görmedin, bilmezsin... Haydi bakalım, şimdi sana Güldane’yi verdim. Şu başındaki kasketi yere çalmaz misın?

- Çalmam... Şapka adamın namusudur. (Tahir, 2007: 100)

Şapkanın bir biat olarak görülmesi, yeni rejime biat ve çıkarın da simgesine dönüştüğü Yol Ayrımı romanina yansir.

Kara şapkalı herif neyin nesiydi acaba? Bana kalsa mebus falan olmalı... Kemal Paşa, 'Sarıklı, sakallı mebus istemem' deyince bu herifler, sakalı kazıtıp ortaya cascavlak çıktılar. Oturak şapkalı gördün mü, bil ki, yobaz eskisi... Ne diyordun? (Tahir, 2010b: 226)

Aynı romanda muhaliflerin vaatleri arasında şapkanın kaldırılacağı sayılır.

Bu sözler, adamına göre değişiyordu. 'Vergileri kaldıracağız' dediler, 'Şekeri beş kuruşa yedireceğiz, tütünü kırk paraya içireceğiz' dediler. 'Din elden gidiyor' denildi, 'Tekkeler açılacak' denildi. Şapkayı defleyip fes giydireceklerine yemin ettiler. Kulaktan kulağa en namuslu insanlara kara sürülmek istendi. (Tahir, 2010b: 457)

Yorgun Savaşçı romanında ise halkın şapkayı bir din aidiyeti olarak algıladığı görülür.

Hele bir Laz Hoca vardı, sıska, tıknefes, gözleri çipil. Ağzından salyalar saçarak yırtınıyordu hergele. 'Boz tomofiiiil... Biri şapkalı dört ittihatçı gâvuru...' diye tepiniyor ki, nerdeyse tıkanıp geberecek... (Tahir, 2005b: 50) 
Kurt Kanunu romanında da şapka, Cumhuriyet'i içselleştirilmediğini, çeşitli anlayışlardaki kişiler için bir cürüm şeklinde ele alınır. İttihatçıların tetikçilerinden Abdülkerim'in hayalinde canlandırdığı sahnede Babıâli’yi basıp içindekileri öldürmek vardır. Suçunu soranlardan birine verdiği cevap da "şapka giymek” şeklindedir. Abdülkerim’le konuşan şoförün "Şapka giydik, diyerek gâvur mu olduk?" cümlesi de şapkanın içselleştirilmediğinin, hala ötekini temsil ettiğini gösterir. Gazete haberlerinde Hicaz Kongresi mümessili Edip Servet'in Hicaz'a gittiğini okuyan Kara Kemal, Edip Servet'in yazıhaneye uğradığını ve şu konuşmanın aralarında geçtiğini söyler:

Bir savaş subayından çok, diplomat yaradılışıı olan Edip Servet geçen gün yazıhaneye uğramıştı. Sıkıntıyla anlattıklarını hatırlayarak gülümsedi. Gazi Paşa sıkı emir vermiş, 'Hicaz'da kesinlikle şapkanı çıkarmayacaksın' diye... Şapkayla Mekke’ye girmek, ölüm cezasına çarptırılmayı gerektiriyormuş... N’apacağını sormuştu, bahtsız temsilciye... 'Düşünüyorum,' diye boynunu bükmüştü Edip Servet, 'karar veremiyorum, yardan mı geçeyim, serden mi?', 'Ne yardan ne serden... Şapkadan geç!', 'Fotoğraf icat edilmeseydi, müzevirler de böyle bir firsat kollamasaydılar, olacağ 1 oydu. ${ }^{15}$ (Tahir, 2008: 85)

Bu alıntı, yukarıda ifade edildiği gibi, şapka bir medeniyet değişiminin yanı sıra yeni rejime itaatin de göstergesi kabul edilmiştir. Ayrıca aynı romanda, Jön Türklerin şapka takmalarının, diğer romanlarda göremediğimiz, bir nedeni daha belirtilir. O da, II. Abdülhamid dönemi istibdadından saklanmak amacını taşır. ${ }^{16}$ Kara Kemal'i evinde sakladığ Bey’e şapkaya karşı olup olmadığı sorulduğunda şöyle cevaplar:

Değilim efendim... Bilirsiniz, Abdülhamit devrinde çok şapka giydik biz... Yabancı postanelerden gizli gazete paketlerini almak için... (Tahir, 2008: 265)

Son olarak; bu romanda, Batılılaşmanın gerçek anlamda 1826 yılında Yeniçerilerin ortadan kaldırılmasıyla başlandığı ifade edilir. Makalemiz bağlamında önemli bir yorum olarak değerlendirebiliriz. Çünkü II. Mahmud fes gibi bir inkılâbı ancak Yeniçeri Ocağı'nı kaldırıp ulema sınıfını desteksiz bıraktıktan sonra gerçekleştirebilmiştir. Dolayısıyla denilebilir ki; batılılaşmanın ilk görsel ifadesi, şapkaya geçişte bir ara durak olan fes olmuştur. "Fes şapka ve kavuk arasında bir geçiş, bir uzlaşma aracıydı." (Özdemir, 2007: 9)

15 Lord Kinross Türkiye'nin gönderdiği bu heyetin sakin bir şekilde karşılandığını belirtir. "Müslüman âlemi, genel olarak devrimi [Şapka İnkılâbını] sakin bir şekilde karşıladı. Gazi, Mekke'de toplanan bir İslam kongresine redingotlu ve şapkalı delegeler gönderdiği zaman, öteki entarili ve sarıklı delegeler bu davranışı normal ve nezaketle karşıladılar.” (Kinross, 1994: 341)

16 "Hüseyin Cahit, 31 Mart Olayı nedeniyle Türkiye'den kaçabilmek üzere vapura binebilmek için şapka giydiğini, ancak Romanya’ya iner inmez kafasına yeniden fes geçirdiğini de anlatmıştı. Bu olayın en önemli yanı 20. yüzyıl başında Osmanlı toprakları içinde bir dokunulmazlık sağlayabilmek için şapkadan medet umulması ve şapkanın simgelediği yabancı güce kimsenin gücünün yetmeyeceğine inanılmasıydı.” (Özdemir, 2007: 21) 


\section{SONUÇ}

Türkiye'nin batılılaşma süreci boyunca şekil-ruh, öz-biçim, iç-kabuk meselesi değişmeyen tartışma konusu olmuştur. Şekilde kalan değişiklikler Tanzimat edebiyatının ilk metinlerinden itibaren karikatürize edilerek ele alınmış ve eleştirilmiştir. Bununla birlikte zihniyet değişimlerinin ister-istemez, bilinçli veya bilinçsiz kıyafete de yansıdığını görürüz. Kıyafet, tercih edilen dünya görüşünün ve mensubiyet hissedilen medeniyete merbutiyeti ilk gözlemde temsil eder. Türkiye'nin medeniyet krizi içine girdiği dönemlerde değişim ve yenileşmelerin giyim kuşama da yansıdığı, özellikle bu değişimlerin başlıklar üzerinde görsel bir sembolleşmeye doğru gittiği görülür. Mecburi tutulan başlık değişimlerini ise; değişen otorite zihniyetini ve otoriteye itaat anlamında bir tür biat istemi olarak görmek mümkündür. Ayrıca hem fes takılması için çıkarılan ferman, hem de şapka takılması için çıkarılan kanun eskiyi hatırlatan her şeyin bertaraf edilmesini de hedeflemiştir. Bu yenilikler karşısında alışkanlıklar, dinî endişeler veya ekonomik kaygılar gibi nedenlerle halkın bir bölümü direnç göstermiş, gösterilen direnç de yine daha sert tedbirlerle püskürtülmüştür.

Bu çalışmada da görüleceği üzere, şapka inkılâbını hususi olarak ele alan, dönemin önemli romancıları tarafından yazılmış, bir romanla karşılaşılmadı. Yapılan inkılâpların kitleler üzerindeki etkilerinin, gözlemlere dayanılarak yazılan romanlar üzerinden okuma imkânı tarih biliminin vermede yetersiz kaldığı pek çok malzeme bulmamızı kolaylaştırabilirdi. Sosyolojik tahliller için de daha bol ve sağlıklı veriler sunardı. Bu nedenledir ki; Şapka Kanunu'nun yürürlüğe girdiği tarihte, fes takmayla ilgili ferman çıkarıldığı dönemde Türk romanı bulunmadığından, ilgili kanunun halk tabakası tarafından nasıl karşılandığını fesin nasıl karşılandığına oranla daha net görebilmekteyiz.

Ele alınan romanlardan takip edebildiğimiz kadarıyla Şapka İnkılâbı, yukarıda da ifade edilen, hedeflediği her iki amaca da ulaşamaz. İlk olarak "tuhaf”, uyumsuz kıyafetlerin düzenlenmesini sağlayamaz. Şapka devrimi öncesi birbiriyle uyumsuz kıyafet görüntüsü şapka ile daha da bir tuhaflığa bürünür. İkinci olarak da, zihniyetin dönüştürülmesi gerçekleştirilemez. Şapkanın altındaki kafada bir değişiklik olmaz; zaten bir başlıktan diğerine geçişle birlikte zihniyetin değişmesini beklemek pek de ayakları yere basan bir hedef değildir. Şapka İnkılâbının tartışmasız şekilde gerçekleştirdiği şey; sembolik anlamda devlet politikası olarak Şark-İslam medeniyetinden ayrılıp Garp medeniyetine intisabı göstermesidir. Oysa otorite, zihniyetine uygun olarak takılacak başlığı, anlam ve değer de yükleyerek, belirleyebilir; ama başlıkla bir kitlenin zihniyetini değiştiremez. Diğer bir ifadeyle şekilsel değişikliklerle bir zihniyet değişikliği yapıldığı ancak zannedilebilir.

Makalede ele alınan yazarların fes-şapka ikileminde nerede durdukları, Şapka Kanunu'nun öncesi ve sonrasında duygularının değişiklik gösterip göstermediği romanların kronolojik yayımı göz önüne alındığında belirlenebilmektedir. Buna göre; Halide Edip, önceleri şapkaya karşı olumsuz duygular içerisindedir. Bununla birlikte; sonraki romanlarında şapkayı benimsemiş görünmektedir. Yakup Kadri, ele alınan yazarlar içerisinde çok erken bir dönemde şapkaya bir 
hikâyeyle dikkatleri çekmiş ve toplumun şapkaya olan kinini abartılı ve gereksiz bulduğunu direkt olmasa da dolaylı olarak belirtmiştir. Bununla birlikte Kurtuluş Savaşı yıllarında sembolik değeri ön plana çıkan fesin işgalci subaylar tarafından hazmedilmemesini de romanına yansıtmıştır. Peyami Safa ise; Osmanlı döneminde başı açık olmanın bir erkek için kabullenilmediğine romanlarında değinir. Anlatımından geleneğin bu dayatmasını gereksiz bulduğu izlenimi vardır. Şapka veya fese ise kendi anlamlarını aşan sembolik anlam ve değerler yüklemez. Refik Halit Karay da toplumun fes ve şapkaya yüklediği sembolik anlamı yansıtmakla birlikte anlatımında bir değer yargısı ifade etmez. Kemal Tahir ise şapkayı bir zihniyet değişiminin göstergesi olarak görür.

Romanda abartı gibi duran ve günümüz değerler sisteminde anlamakta zorluk çektiğimiz fes-şapka ile ilgili değerlendirmeler ve sahnelerin benzerlerini bu dönemi ele alan anılarda da görürüz. Dolayısıyla romanlarda karşılaştığımız sahnelerin abartılı bir kurgu unsuru olarak işlenmediği anlaşılır.

Son olarak bilinmesi gereken bir nokta; Mustafa Kemal'in bu inkılâbı aslında zannedilenin aksine benzersiz, öncesiz değildir. Ortadoğu ülkeleri başta olmak üzere benzeri çokça görülen bir girişimdir. ${ }^{17}$ Hatta Falih Rıfkı'nın belirttiğine göre; "Büyük Petro, Ortodoks Ruslara kalpak yerine şapka giydirebilmek için Moskova şehrinin etrafını topçu bataryaları ile çevirmişti." (Atay, 2009: 430) Başlık, otoriteyi ele geçirenin benimsediği ve halkının da benimsemesini istediği, aksini itaatsizlik olarak gördüğü temsili bir değişimdir. Abbasilerden Osmanlılara kadar geçen sürede bunun pek çok örneğini göstermek mümkündür. Şapka İnkılâbından sadece yüz yıl öncesini ele aldığımızda bile sarık-fes-keçe külah-kalpak ve şapka şeklinde her biri farklı bir ideolojik/düşünsel sembolizasyona tekabül eden değişimler görülür.

Hakem Değerlendirmesi: Dış bağımsız.

Çıkar Çatışması: Yazar çıkar çatışması bildirmemiştir.

Finansal Destek: Yazar bu çalışma için finansal destek almadığını beyan etmiştir.

Peer-review: Externally peer-reviewed.

Conflict of Interest: The author has no conflict of interest to declare.

Grant Support: The author declared that this study has received no financial support.

\section{KAYNAKÇA/REFERENCES}

Abalı, N. (2009). Geleneksellik ve Modernizm Açısından Kılık Klyafet. İstanbul: İlke.

Adıvar, H. E. (2006). Zeyno'nun Oğlu. İstanbul: Özgür.

Adıvar, H. E. (2009). Tatarcık. İstanbul: Can.

17 17.Yüzyıldan 20.Yüzyıl Sonuna Kadar Avrupa'da Toplumsal Süreçlerin Şapka Biçimlerine Etkisi adlı yüksek lisans tezinde Gizem Erkuş, Avrupa'da da benzer şekilde, ilk çağlardan itibaren, her toplumsal dönüşümün başlıklara yansıdığını ve başlıkların her dönemde farklı sembolik değerler yüklendiğini görsel malzemelerle destekleyerek anlatır. Daha fazla bilgi için ilgili teze bakılabilir. 
Adıvar, H. E. (2013). Sinekli Bakkal. İstanbul: Can.

Atay, F. R. (2009). Çankaya. İstanbul: Pozitif.

Aysal, N. (2011). “Tanzimat’tan Cumhuriyet'e Giyim ve Kuşamda Çağdaşlaşma Hareketleri”. Çağdaş Türkiye

Tarihi Araştırmaları Dergisi 10(22), 3-32. https://dergipark.org.tr/tr/pub/cttad/issue/25243/266919

Elmac1, M. E. (1997). Fes-Kalpak Mücadelesi. Toplumsal Tarih, 42.

Erduğan, T. (2019). Türkiye ’nin Modernleşme Sürecinde Bir Simge: Şapka Inkılâbı. Yayımlanmamış Yüksek Lisans Tezi. Bartın, Bartın Üniversitesi Sosyal Bilimler Enstitüsü.

Erkuş, G. (2013). 17. Yüzyıldan 20.Yüzyıl Sonuna Kadar Avrupa'da Toplumsal Süreçlerin Şapka Biçimlerine Etkisi. Yayımlanmamış Yüksek Lisans Tezi. İstanbul, Beykent Üniversitesi Sosyal

Bilimler Enstitüsü.

Güntekin, R. N. (2008). Ateş Gecesi. İstanbul: İnkılâp.

Güntekin, R. N. (2015). Yeşil Gece. İstanbul: İnkılâp.

Güntekin, R. N. (2016). Gizli El. İstanbul: İnkılâp.

Hür, A. (2013). Öteki Tarih 2. İstanbul: Profil.

Karaosmanoğlu, Y. K. (1966). Sodom ve Gomore. Ankara: Bilgi.

Karaosmanoğlu, Y. K. (1969). Gençlik ve Edebiyat Hatıraları. Ankara: Bilgi.

Karaosmanoğlu, Y. K. (1983). Panorama, İstanbul: İletişim.

Karaosmanoğlu, Y. K. (1990). Bir Serencam. İstanbul: İletişim.

Karaosmanoğlu, Y. K. (1996). Kiralık Konak. İstanbul: İletişim.

Karay, R. H. (2009a). Yezidin Klzı. İstanbul: İnkılâp.

Karay, R. H. (2009b). Bu, Bizim Hayatımız. İstanbul: İnkılâp.

Karay, R. H. (2014a). Bugünün Saraylısı. İstanbul: İnk1lâp.

Karay, R. H. (2014b). Deli. İstanbul: İnk1lâp.

Lord K. (1994). Atatürk Bir Milletin Yeniden Doğuşu. İstanbul: Altın Kitaplar.

Moran, B. (2001). Türk Romanına Eleştirel Bir Bakış. İstanbul: İletişim.

Özdemir, K. (2007). Cumhuriyet Döneminde Şapka Devrimi ve Tepkiler. Yayımlanmamış Yüksek

Lisans Tezi. Eskişehir Anadolu Üniversitesi Sosyal Bilimler Enstitüsü.

Pakalın, M. Z. (1993). Osmanlı Tarih Deyimleri ve Terimleri Sözlüğü I. İstanbul: Milli Eğitim Bakanlı̆̆ı.

Safa, P. (1996). Mahşer. İstanbul: Ötüken.

Safa, P. (1998). Bir Tereddüdün Romanı. İstanbul: Ötüken.

Safa, P. (2010). Türk Inkılabına Bakışlar. İstanbul: Ötüken.

Safa, P. (2016). Sözde Klzlar. İstanbul: Ötüken.

Sarı, E. (2016). Karacaoğlan, Antalya: Nokta.

Tahir, K. (2005a). Esir Şehrin Insanları. İstanbul: İthaki.

Tahir, K. (2005b). Yorgun Savaşçı. İstanbul: İthaki.

Tahir, K. (2007). Sağırdere. İstanbul: İthaki.

Tahir, K. (2008). Kurt Kanunu. İstanbul: İthaki.

Tahir, K. (2010a). Hür Şehrin Insanları. İstanbul: İthaki.

Tahir, K. (2010b). Yol Ayrımı. İstanbul: İthaki. 
